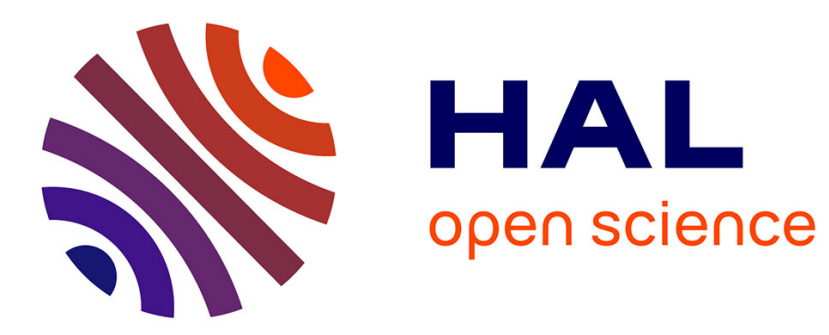

\title{
Thermal Evolution of Asymmetric Hyperextended Magma-Poor Rift Systems: Results From Numerical Modeling and Pyrenean Field Observations
}

Rodolphe Lescoutre, Julie Tugend, Sascha Brune, Emmanuel Masini, Gianreto Manatschal

\section{To cite this version:}

Rodolphe Lescoutre, Julie Tugend, Sascha Brune, Emmanuel Masini, Gianreto Manatschal. Thermal Evolution of Asymmetric Hyperextended Magma-Poor Rift Systems: Results From Numerical Modeling and Pyrenean Field Observations. Geochemistry, Geophysics, Geosystems, 2019, 20 (10), pp.4567-4587. 10.1029/2019GC008600 . hal-03102455

\section{HAL Id: hal-03102455 \\ https://hal.science/hal-03102455}

Submitted on 20 Dec 2021

HAL is a multi-disciplinary open access archive for the deposit and dissemination of scientific research documents, whether they are published or not. The documents may come from teaching and research institutions in France or abroad, or from public or private research centers.
L'archive ouverte pluridisciplinaire HAL, est destinée au dépôt et à la diffusion de documents scientifiques de niveau recherche, publiés ou non, émanant des établissements d'enseignement et de recherche français ou étrangers, des laboratoires publics ou privés. 

Geosystems

\author{
RESEARCH ARTICLE \\ 10.1029/2019GC008600 \\ Key Points: \\ - Numerical modeling and field \\ observations of asymmetric rifts \\ show an asymmetric thermal \\ evolution during hyperextension \\ - Asymmetric rift basins can record \\ diachronous heat peaks resulting \\ from different successive thermal \\ events (formation of allochthons) \\ - Determination of thermal gradients \\ from peak temperatures may be \\ misleading as the thermal \\ architecture results from \\ diachronous evolution
}

Supporting Information:

- Supporting Information S1

- Table S1

- Table S2

- Movie S1

Correspondence to:

R. Lescoutre,

rodolphe.lescoutre@unistra.fr

Citation:

Lescoutre, R., Tugend, J., Brune, S., Masini, E., \& Manatschal, G. (2019). Thermal evolution of asymmetric hyperextended magma-poor rift systems: Results from numerical modeling and Pyrenean field observations. Geochemistry, Geophysics, Geosystems, 20, 4567-4587. https:// doi.org/10.1029/2019GC008600

Received 5 AUG 2019 Accepted 28 SEP 2019 Accepted article online 14 OCT 2019 Published online 29 OCT 2019

(C)2019. American Geophysical Union. All Rights Reserved.

\section{Thermal Evolution of Asymmetric Hyperextended Magma-Poor Rift Systems: Results From Numerical Modeling and Pyrenean Field Observations}

\author{
Rodolphe Lescoutre $^{1}$ (D), Julie Tugend ${ }^{1,2,3}$ iD, Sascha Brune ${ }^{4,5}$ (D), Emmanuel Masini ${ }^{3}$, and \\ Gianreto Manatschal ${ }^{1}$ iD \\ ${ }^{1}$ IPGS, EOST-CNRS, Université de Strasbourg, Strasbourg, France, ${ }^{2}$ Sorbonne Université, CNRS-INSU, Institut des \\ Sciences de la Terre Paris, ISTeP UMR 7193, Paris, France, ${ }^{3}$ Total R\&D, CSTJF, Pau, France, ${ }^{4}$ GFZ Potsdam, German \\ Research Centre for Geosciences, Potsdam, Germany, ${ }^{5}$ Institute of Earth and Environmental Sciences, University of \\ Potsdam, Potsdam, Germany
}

\begin{abstract}
We investigate the thermal and structural evolution of asymmetric rifted margin using numerical modeling and geological observations derived from the Western Pyrenees. Our numerical model provides a self-consistent physical evolution of the top basement heat flow during asymmetric rifting. The model shows a pronounced thermal asymmetry that is caused by migration of the rift center toward the upper plate. The same process creates a diachronism for the record of maximum heat flow and maximum temperatures $\left(T_{\max }\right)$ in basal rift sequences. The Mauléon-Arzacq basin (W-Pyrenees) corresponds to a former mid-Cretaceous asymmetric hyperextended rift basin. New vitrinite reflectance data in addition to existing data sets from this basin reveal an asymmetry in the distribution of peak heat $\left(T_{\max }\right)$ with respect to the rift shoulders, where highest values are located at the former upper- to lower-plate transition. This data set from the Arzacq-Mauléon field study confirms for the first time the thermal asymmetry predicted by numerical models. Numerical modeling results also suggest that complexities in synrift thermal architecture could arise when hanging-wall-derived extensional allochthons and related $T_{\max }$ become part of the lower plate and are transported away from the upper- to lower-plate transition. This study emphasizes the limitations of the common approach to integrate punctual thermal data from pre-rift to synrift sedimentary sequences in order to describe the rift-related thermal evolution and paleothermal gradients at the scale of a rift basin or a rifted margin.
\end{abstract}

\section{Introduction}

Over the past decade, our understanding of hyperextended rift systems greatly improved, thanks to a combination of new seismic interpretations from present-day rifted margins (e.g., Autin et al., 2010; Osmundsen \& Ebbing, 2008; Reston \& McDermott, 2011), field observations from fossil analogs (e.g., Clerc et al., 2016; Frasca et al., 2016; Masini et al., 2014), and novel numerical modeling techniques (Duretz et al., 2016; Huismans \& Beaumont, 2014; Lavier \& Manatschal, 2006). The first-order architecture of rifted margins has been widely described and subdivided into "structural" rift domains (Péron-Pinvidic et al., 2013, 2017; Sutra et al., 2013; Tugend et al., 2015), one of which being referred to as the "hyperextended domain." Hyperextended rift systems have been reproduced in various numerical experiments, which demonstrated that these systems show an overall asymmetry of the conjugate margin architecture and a shift of the rising asthenosphere (Brune et al., 2014; Jammes \& Lavier, 2016; Svartman Dias et al., 2015; Tetreault \& Buiter, 2017). A diachronous evolution is also observed in the overlying sedimentary sequence as indicated by the migration of the syn-tectonic sequence toward the exhumation point, which corresponds to the newly exposed surface in the footwall of a detachment fault.

Previous studies explored the distribution of heat within present-day (Leroy et al., 2010; Lucazeau et al., 2008) and fossil rift systems (Beltrando et al., 2015; Chelalou et al., 2016; Clerc et al., 2015; Hart et al., 2016, 2017; Vacherat et al., 2014) to define the thermal architecture of hyperextended rift basins. Despite these recent studies, the thermal evolution and architecture of rifted margins and especially the consequence of asymmetric rifting remain poorly understood. Notably, the spatial and temporal evolution of rift systems is 
shown to be complex (Alves et al., 2009; Mohn et al., 2015; Naliboff et al., 2017; Savva et al., 2014; Tugend, Manatschal, Kusznir, \& Masini, 2015) and its control on the rift-related thermal evolution remains at present unconstrained. Simple correlations between isolated, punctual observations within a rift system and the overall thermal architecture and evolution of the entire basin are not straightforward. This is particularly important for rifted margins where several heat sources with different thermal amplitudes and durations are recognized (Ungerer et al., 1990) and where the structural evolution is shown to be complex through time (e.g., Péron-Pinvidic et al., 2013). All these complexities do not favor 3-D extrapolation from local thermal measurements only and ask for a better understanding of the processes controlling the thermal evolution during rifting and particularly during extreme crustal thinning and mantle exhumation. From an industrial perspective, understanding the processes controlling the thermal evolution of basins is fundamental to model and predict petroleum systems that could be extremely different between conjugate pairs of asymmetric rifted margins (e.g., maturation and timing of migration of hydrocarbons). Thus, progress on this topic has strong impact on the exploration potential of ultradeep offshore settings. In that aspect, the former Arzacq-Mauléon hyperextended rift basin preserved in the Western Pyrenees represents a unique opportunity to assess the entire pre-rift to synrift sedimentary sequence, which is a prerequisite to unravel the thermal evolution of these systems during their formation.

In this study, we modified a 2-D numerical model of Brune et al. (2014) to analyze top basement heat flow evolution and to define the first-order heat distribution during asymmetric lithospheric thinning based on 1-D thermal basin models. In parallel, we investigate the thermal structure of the fossil asymmetric Arzacq-Mauléon rift basin for which we present unpublished vitrinite reflectance data (proxy for $T_{\max }$ ) from boreholes acquired by Elf Aquitaine (now Total) in the 1980s. This study allows us to test the numerical model predictions and to highlight some geological and thermal complexities using a natural example. We then emphasize implications of the results concerning the thermal evolution of extensional allochthons or more generally of allochthonous extensional units. Note that we explicitly focus in this study on the synrift evolution and do not aim to predict the final thermal architecture of the whole basin, which depends also on its post-rift infill history. Through this work, we emphasize the necessity of understanding the rift evolution to better constrain the crustal/lithospheric thermal architecture of hyperextended rift basins.

\section{Asymmetric Rifted Margins: Observations and Concepts}

Numerous examples of conjugate asymmetric rift systems have been observed and described worldwide across the North and South Atlantic margins (e.g., Blaich et al., 2011; Chian et al., 1995; Péron-Pinvidic et al., 2013, 2017) or the Australia-Antarctica margins (e.g., Espurt et al., 2012; Gillard et al., 2016). This asymmetry is noticeable from a crustal and structural point of view (Figure 1; Nirrengarten et al., 2016). One of the margins shows a generally wider crustal taper, mainly exhibiting oceanward dipping detachment faults rooting onto the Moho (Figure 1, right side: Iberia, Labrador, and Celtic platform margins). The conjugate margin generally shows a sharper crustal taper and a complex structural pattern with oceanward and continentward dipping high-angle normal faults (Figure 1, left side: Newfoundland, West Greenland, and Porcupine High). This asymmetry was classically interpreted as related to different geometries between lower and upper plate margins, respectively, based on the concept first introduced by Lister et al. (1986). As such, upper and lower plate margins can be defined relatively to a major (or a succession of) detachment fault system(s), respectively, corresponding to the hanging wall and footwall of the major active detachment fault.

Recent studies suggest that this asymmetry is mainly acquired during the formation of the hyperextended domain (e.g., Nirrengarten et al., 2016), bounded landward by the necking domains and seaward by the oceanic domain (e.g., Péron-Pinvidic et al., 2013; Sutra et al., 2013). Numerical models suggest that the asymmetry of a rifted margin is mainly controlled by the extensional rate and the rheology (Huismans \& Beaumont, 2002). In the hyperextended domain, the crust is sufficiently thinned so that brittle behavior prevails and deformation is largely coupled at the scale of the crust (Pérez-Gussinyé \& Reston, 2001; Sutra \& Manatschal, 2012). The formation of upper and lower plates in the hyperextended domain is associated with progressive rift migration and sequential normal faulting (Brune et al., 2014; Haupert et al., 2016; Lister et al., 1986; Ranero \& Pérez-Gussinyé, 2010; Svartman Dias et al., 2015). Furthermore, applying the critical Coulomb wedge theory to predict deformation in hyperextended domains, Nirrengarten et al. (2016) showed that extensional allochthons can form and migrate from the upper to the lower plate. Once mantle is 

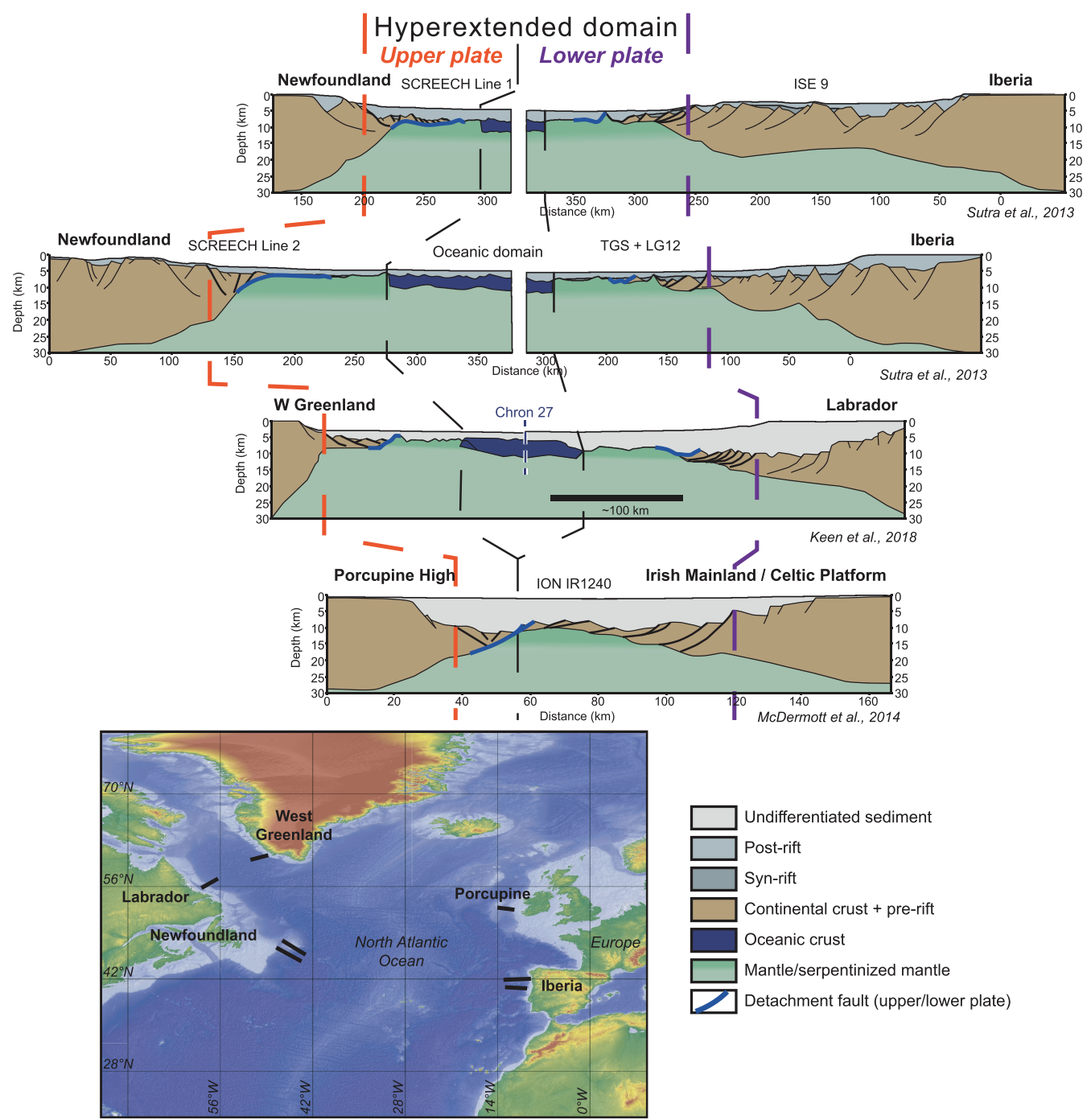

Figure 1. Examples of asymmetric rifted margins and basins from the Northern Atlantic. The asymmetry is interpreted as related to differences between lower- and upper-plate architectures formed during hyperextension. Iberia-Newfoundland after Sutra et al. (2013); Labrador-West Greenland after Keen et al. (2018); and Porcupine basin after McDermott et al. (2014). The hyperextended domain corresponds to the coupled domain defined by Sutra et al. (2013).

exhumed and no crust remains, out-of-sequence faulting may occur and can lead to a more symmetric structural evolution (Gillard et al., 2016).

Coincident with this asymmetric crustal structure, the overlying stratigraphic architecture differs between upper and lower plates. The first order stratigraphic architecture of the lower and upper plate margins is schematically shown in Figure 2 together with the terminology used to describe the synrift stratigraphic sequence. Most of the crustal thinning in the upper plate is interpreted as accommodated by intracrustal extension associated with simultaneous detachment faulting on the conjugate lower plate. This leads to the preservation of an upper crustal block with a generally more continuous/preserved pre-rift stratigraphy (Haupert et al., 2016; Péron-Pinvidic et al., 2017). As such, sediments deposited onto the upper plate are progressively stacked and include pre-rift to synrift sediments. On the lower plate, progressive in-sequence detachment faults result in complex stratigraphic architectures combining classical growth strata and subhorizontal deposition of synrift sediments (e.g., Masini et al., 2011; Tugend, Manatschal, Kusznir, \& Masini, 2015) onto exhumed deep crustal and mantle rocks. The sediments deposited onto the active exhumation fault are younging toward the hanging wall (i.e., upper plate) and are mainly synrift to post-tectonic. During the exhumation process, crustal blocks can be pulled out from the upper plate and loaded onto the 


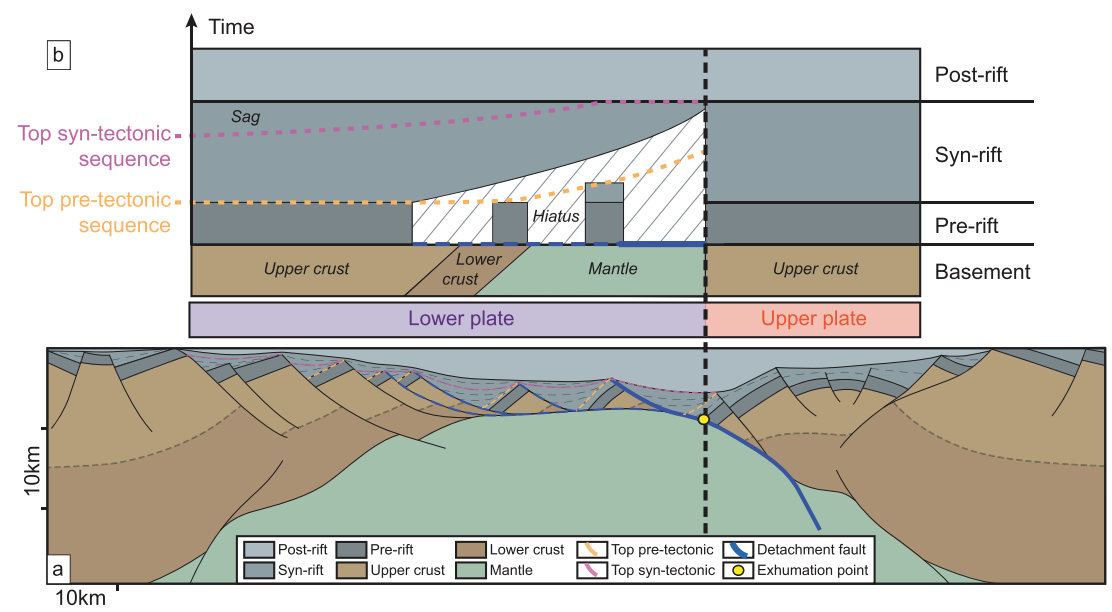

Figure 2. (a) Concept of upper/lower plate showing the related asymmetric crustal and sedimentary architecture. For simplicity, in this model, no decoupling level is considered between the sediments and the basement. Deep crustal rocks can be exhumed in the footwall of detachment faults on the lower plate. Allochthonous blocks are progressively delaminated and migrate from the upper to the lower plate (Nirrengarten et al., 2016). (b) Wheeler diagram showing the expected stratigraphic architecture of pre-rift, synrift, and post-rift sediments. The top of the pre-tectonic sequence delimits sediments that are not affected by extensional deformation. The top of the syn-tectonic sequence corresponds to the limit between sediments deposited during active faulting and those deposited during the post-tectonic "sag" phase (as defined in Masini et al., 2014). Note the younging of the syn-tectonic sequence toward the exhumation point.

lower plate (Nirrengarten et al., 2016). Thus, such blocks change from an upper to a lower plate position. The stratigraphic architecture associated to these so-called extensional allochthons is complex (e.g., Masini et al., 2011), as they can preserve pre-rift to synrift sediments over exhumed surfaces and they are often overlain by post-rift sediments.

These structural and stratigraphic observations allow the identification of key criteria to discriminate upper and lower plates. To summarize, the lower plate shows a complex structure and abundant accommodation space, generally associated with a wider zone of exhumed deep basement rocks capped by a detachment surface and extensional allochthons (Péron-Pinvidic et al., 2017). The architecture of the upper plate shows preserved upper crustal rocks overlain by typical syn-tectonic sedimentary wedges associated with tilted blocks and little syn-tectonic accommodation space compared to the lower plate margin (Péron-Pinvidic et al., 2017).

\section{Numerical Model of Asymmetric Rifting}

\subsection{Setup, Inputs, and Updates}

The numerical model presented here provides a dynamic description of an asymmetric rift system, which captures the first-order rift architecture and evolution of the hyperextended basins such as described in the previous section. The simulation is based on the Iberia-Newfoundland model presented in Brune et al. (2014); Brune et al., 2017) and employs the finite element code SLIM3D (Popov \& Sobolev, 2008). This code captures viscoelastoplastic deformation processes of the lithosphere such as ductile flow in the lower crust (Clift et al., 2015) and the asthenosphere (Brune et al., 2013; Koopmann et al., 2014), normal faulting (Brune, 2014), and associated evolution of lithospheric stress (Brune et al., 2012, 2016). Brittle deformation is represented through Mohr-Coulomb plasticity and localization of faults is further facilitated via the standard approach of strain-dependent friction softening (Huismans \& Beaumont, 2003). All model parameters are provided in the supporting information Table S1.

The computed 2-D model is $500 \mathrm{~km}$ wide, $150 \mathrm{~km}$ deep, and uses four distinct layers and flow laws: upper crust (22 km thick, wet quartzite flow law of Gleason \& Tullis, 1995); lower crust (11 km thick, wet anorthite flow law of Rybacki \& Dresen, 2000); strong lithospheric mantle (dry olivine flow law of Hirth \& Kohlstedt, 2003), and weak asthenospheric mantle (wet olivine flow law, Hirth \& Kohlstedt, 2003). The lithosphereasthenosphere boundary (set to $1300{ }^{\circ} \mathrm{C}$ ) is initially located at $105 \mathrm{~km}$ depth. The employed values for prerift layer thicknesses lie within the possible range suggested by geophysical models of neighboring less 
deformed areas (Díaz \& Gallart, 2009; Tesauro et al., 2009; Torne et al., 2015); however, it has to be noted that layer thicknesses at rift onset and associated rheological flow laws are among the most poorly constrained model parameters.

The surface temperature is set to $0{ }^{\circ} \mathrm{C}$ and the bottom temperature to $1300{ }^{\circ} \mathrm{C}$. Between these top and bottom boundary conditions, the initial thermal state is controlled by heat advection, radiogenic heat production, and heat conductivity of each specific layer. As such, the initial Moho temperature corresponds to $600{ }^{\circ} \mathrm{C}$ and the initial surface heat flow to $67 \mathrm{~mW} / \mathrm{m}^{2}$.

The setup reproduces a passive rift where the rise of the lithosphere-asthenosphere boundary is controlled by lithospheric thinning due to a prescribed full extension velocity of $8 \mathrm{~mm} /$ year. The asymmetry of the model develops self-consistently and is controlled by crustal rheology, thermal configuration, and strain-dependent softening. A randomly distributed small amount of initial strain is used to break the symmetry such that the fault orientation and distribution is not predetermined by the model and asymmetric rifting can freely proceed. Evolution of topography is allowed via a free surface boundary condition and the isostatic equilibrium at the bottom boundary is controlled by the Winkler foundation including in and outflow of material (Gerya, 2019; Popov \& Sobolev, 2008; Yamato et al., 2008).

In order to keep the model as transparent and simple as possible and to stay general rather than focus on specific rift settings, we do not account for some processes that are generally thought to affect the dynamics of rift systems. For instance, magmatic additions are not included in the model, as their volumes are highly limited in magma-poor rift systems. Also, the role of fluids on local heat flow variations is not represented as it is probably of subordinate importance at the scale (time and space) of the model. The reference model does not take into account sedimentary infill and related loading blanketing by the sedimentary infill, nor the burialrelated thermal history. However, models with low and high sediment infills have also been performed (Figure S2), but the results show that including a realistic sedimentary infill for asymmetric rifting $(<6 \mathrm{~km}$ of synrift sediments) does not affect our conclusions on the top basement heat flow evolution. In order to avoid the strong thermal impulse involved by the formation of oceanic crust and to consider only the thermal evolution associated to rifting, the modeled extension stops shortly prior to lithospheric breakup inducing thermal relaxation that lasts until the end of the model run. In the following, we describe the heat flow as well as its evolution at different locations at the base of the basin (top basement).

\subsection{Thermal Evolution of Rifted Margins: Numerical Model Results}

The model (Figure 3 and Movie S3) illustrates that the deformation localizes onto major asymmetric border faults, while shearing occurs in the ductile layers of the model. It should be noted that the top of the crust always displays an elastoplastic behavior in the model. Rapid rheological coupling accounts for the formation of in-sequence faulting associated with upwelling of the lithosphere-asthenosphere boundary at the tip of the active fault. Antithetic normal faults control the deformation of the brittle upper crust in the hanging wall of the active extensional fault, while a low-viscosity pocket forms in the lower crust (Figure 3, stage 2 and Brune et al., 2014). As suggested in Brune et al. (2014), rift migration could be caused by the lateral strength gradient between the low-viscosity pocket and the cooling mantle at the footwall of the active fault. As a consequence, the rift shows a typical upper- to lower-plate architecture and a crustal scale detachment that is well expressed on the 13.5 Myr snapshot (Figure 3, stage 2). On the lower plate (left side), detachment faults thin the crust to a thickness $<10 \mathrm{~km}$ at the center of the basin.

The overall geometry reveals a wide lower plate and a relatively sharp upper plate margin configuration once hyperextension begins (i.e., at about $9 \mathrm{Myr}$ ). From that moment on, the distribution of the heat flow at each time step remains asymmetric with respect to the rift shoulders (Figure 3, stages 2 and 3). The location of the maximum heat flow corresponds to the active deformation area, that is, at the limit between the upper and the lower plate. Regarding the displacement of markers A, B, and C, we see that A is moving toward the left (with the lower plate) from $x=240$ to $x=220 \mathrm{~km}$ between stages 1 and 2, while B and C slightly move toward the right during this time. From stage 2 to stage 3, markers A and B move for about $25 \mathrm{~km}$ toward the left while $\mathrm{C}$ is only slightly displaced.

We extract the evolution of heat flow experienced by each marker (A, B, and C) through time (Figure 4). We find that marker A records heat flow, which starts at $70 \mathrm{~mW} / \mathrm{m}^{2}$, reaches $110 \mathrm{~mW} / \mathrm{m}^{2}$ at about $10 \mathrm{Myr}$ and then slowly decreases to $90 \mathrm{~mW} / \mathrm{m}^{2}$. The heat flow at marker B is at first almost constant at $70 \mathrm{~mW} / \mathrm{m}^{2}$, and 


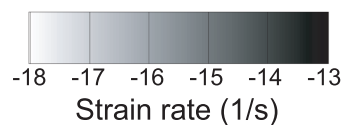

Strain rate $(1 / \mathrm{s})$
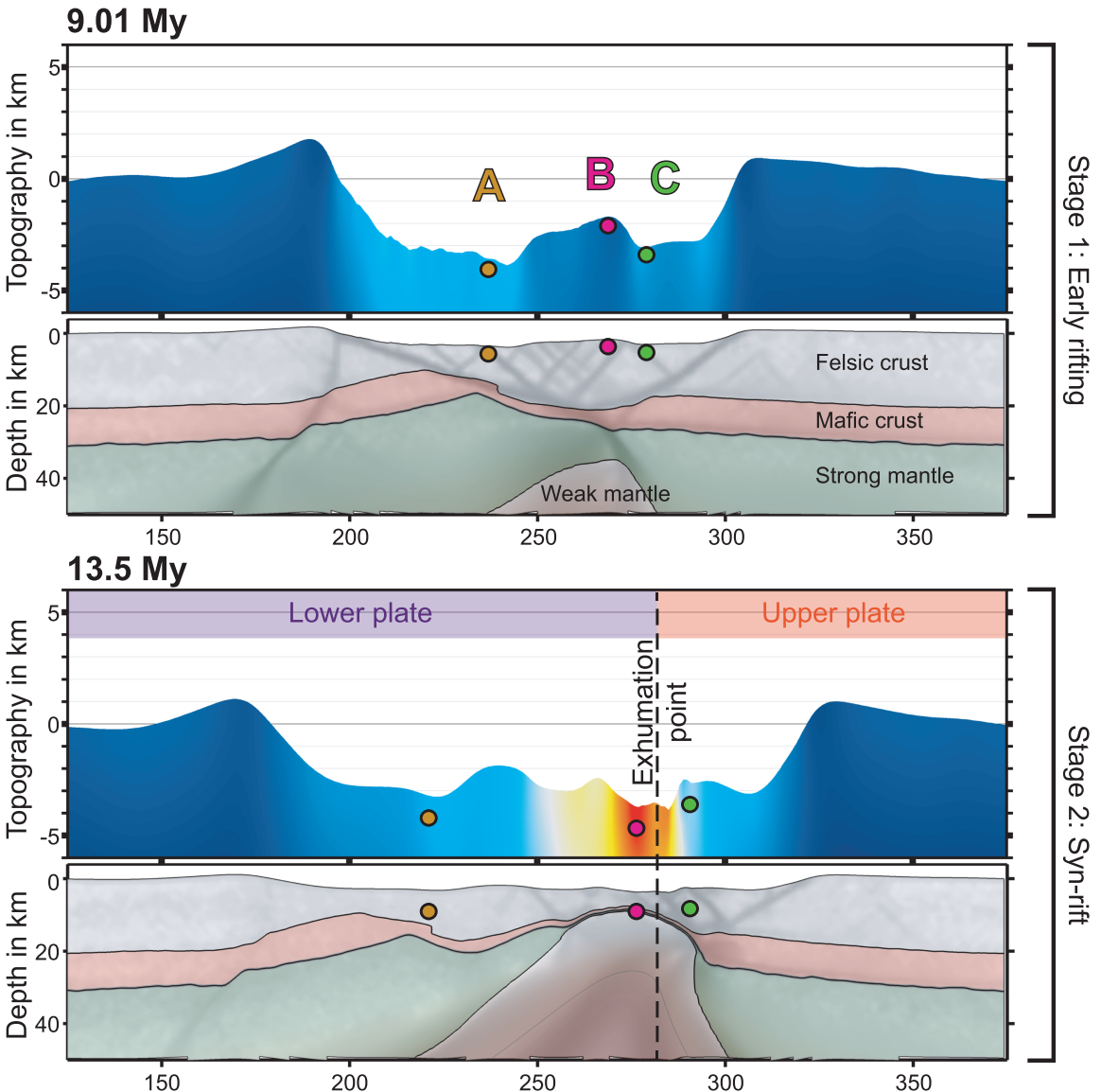

18.5 My

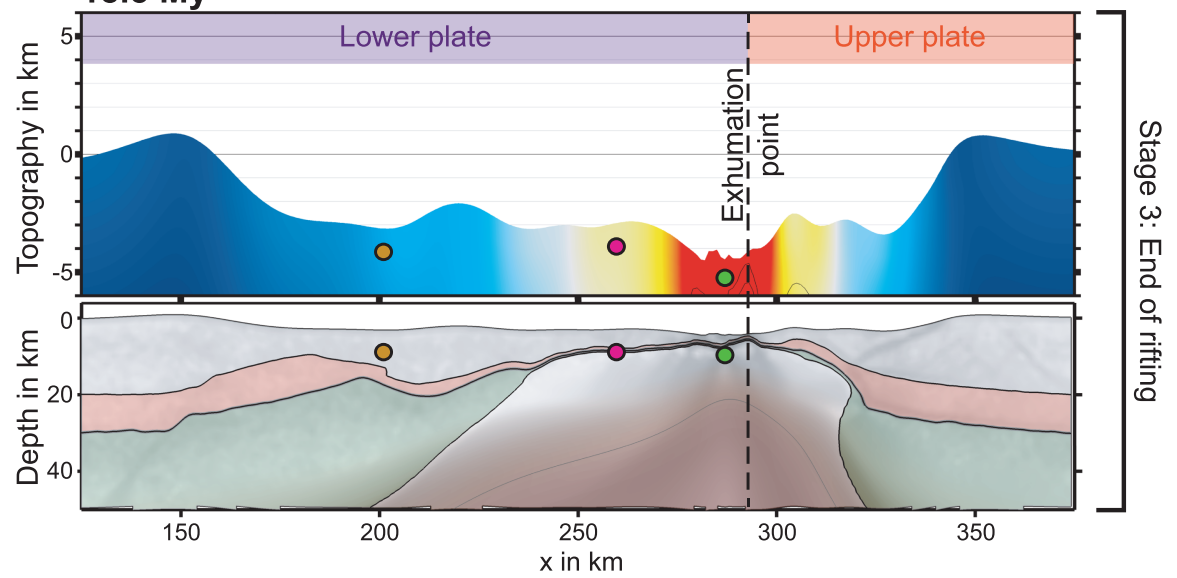

Figure 3. Snapshots of the dynamic model (see supporting information Movie S3) at 9.01 Myr (stage 1: early rifting, top panel), 13.5 Myr (stage 2: intermediate stage of rifting, middle panel), and 18.5 Myr (stage 3: end of rifting, bottom panel). The deformation of the different lithospheric layers is displayed in terms of semitransparent strain rate (i.e., the logarithm of the second invariant of the strain rate tensor) at each time step. The evolution of the topography and the distribution of heat flow at the top of the basement are also shown. The topography highlights the tilted blocks and the location of the major faults at surface. Markers A, B, and C within the crust illustrate the formation of extensional allochthons due to the migration of the deformation toward the upper plate via in-sequence detachment faulting. Note the higher horizontal thermal gradient on the upper plate and the position of the maximum heat flow with respect to the deformation during hyperextension. 


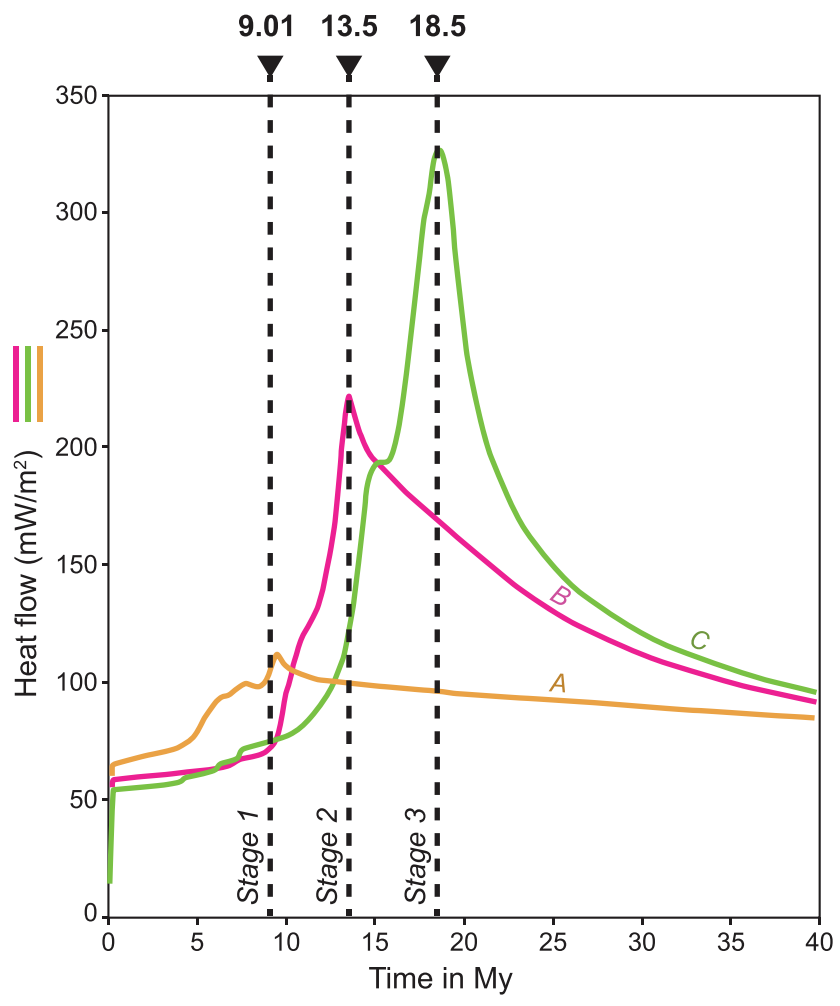

Figure 4. Heat flow evolution for the three markers A, B, and C during rifting (see Figure 3 for location). A general increase of the maximum heat flow through time is highlighted. Maximum heat flow for each marker A, B, and C is diachronous.

from $10 \mathrm{Myr}$ on it increases to reach a maximum of about $225 \mathrm{~mW} / \mathrm{m}^{2}$ at $13.5 \mathrm{Myr}$. The heat flow quickly decreases even before the end of rifting at $19 \mathrm{Myr}$ to a value of $165 \mathrm{~mW} / \mathrm{m}^{2}$. Similarly, marker C shows a rapid increase from $12 \mathrm{Myr}$ to a maximum of $325 \mathrm{~mW} / \mathrm{m}^{2}$ at $19 \mathrm{Myr}$.

These results evidence a diachronism (Figure 4) in the record of maximum heat flow for the three markers in the asymmetric rift model. Moreover, maximum heat flow at the base of the basin is constantly increasing with time due to the progressive thinning of the lithosphere. Such basal heat flow trend is similar for the model with moderate sedimentation rates (Figure S2) except that the heat flow value remains high for much longer due to the lower thermal conductivity of the sediments and the limitations of the model to progressively fill the basin. The diachronous migration of markers from the right side of the main detachment fault to the left (i.e., from upper to lower plate) is due to rift migration. This shows that rocks from the upper plate at the beginning of rifting are eventually transferred to the lower plate where they form extensional allochthons (Brune et al., 2014; Nirrengarten et al., 2016). Maximum heat flow (Figure 3, stages 2 and 3) occurs at the location of maximum strain rate, that is, near the detachment fault system along which deep crustal and mantle rocks are exhumed. For a similar crustal thickness, the top basement heat flow can display very different values (e.g., in Figure 3, for crustal thickness of about $6 \mathrm{~km}$ at 18.5 Myr: for $x=250 \mathrm{~km}$, heat flow $\approx 150 \mathrm{~W} / \mathrm{m}^{2}$; for $x=270 \mathrm{~km}$, heat flow $\approx 190 \mathrm{~W} / \mathrm{m}^{2}$; for $x=305 \mathrm{~km}$, heat flow $\approx 170 \mathrm{~W} / \mathrm{m}^{2}$ ). Moreover, it is important to note that, at $13.5 \mathrm{Myr}$ (stage 2), the location of the maximum heat flow $\left(250 \mathrm{~mW} / \mathrm{m}^{2}\right)$ is very close (less than $\left.50 \mathrm{~km}\right)$ to the rift shoulder of the upper plate, where heat flow is less than $70 \mathrm{~mW} / \mathrm{m}^{2}$. This generates a horizontal gradient for heat flow of about $3.5 \mathrm{~mW} / \mathrm{m}^{2}$ per kilometer for the upper plate (rift shoulder to upper- to lower-plate transition) and of about $1.4 \mathrm{~mW} / \mathrm{m}^{2}$ per $\mathrm{km}$ for the lower plate (distance of $125 \mathrm{~km}$ ).

In summary, numerical modeling illustrates a strong asymmetry on the distribution of maximum basal heat flow during asymmetric rifting, considering a low to moderate sedimentation rate (Figures 3 and S2). Indeed, the maximum heat flow is located in and around the active exhumation point, which corresponds to the upper- to lower-plate transition in our interpretation (Figure 2). This results in an asymmetric thermal 
configuration with a sharp horizontal gradient in heat flow on the upper plate and a significantly smoother variation on the lower plate. This relationship mirrors the crustal architecture of the model with a sharp upper plate and a wide lower plate margin. As expressed in the graph in Figure 4, a consequence of this model is the successive migration of upper plate rocks undergoing very high heat flow onto the lower plate, where heat flow is quickly decreasing leading to a diachronous heat flow evolution for each extensional allochthon.

\subsection{Influence of Rift Asymmetry on $T_{\max }$ in Synrift Basins}

In contrast to the previous section, where we described the results of an asymmetrical rift model, this section aims to deduce the implications for the thermal architecture of a synrift basin. In particular, we investigate when and where the highest temperatures $\left(T_{\max }\right)$ are recorded in the basin. Based on the modeled heat flow histories of points A, B, and C (Figure 5a), we compute the temperature at the base of the sedimentary column by means of a simple 1-D basin model that solves the heat equation for a homogeneous sedimentary column that is submitted to a time-dependent modeled basement heat flux from below and a fixed surface temperature of $5^{\circ} \mathrm{C}$ at the top. We set the conductivity of the sediments to $2.77 \mathrm{~W} \cdot \mathrm{m}^{-1} \cdot \mathrm{K}^{-1}$ (Pasquale et al., 2015) corresponding to marls and the radiogenic heat production to $1.392 \mu \mathrm{W} / \mathrm{m}^{3}$ (Vilà et al., 2010). We use a $1 \mathrm{~km}$ thick pre-rift sequence that is covered at constant rate by synrift sediments involving two end-member scenarios (Figure 5b). The resulting temperature is measured at the base of the pre-rift sediments. Compaction, fluids, or thermal blanketing that are known to influence heat distribution at local scale are not taken into account for simplicity.

Two models are presented (Figures $5 \mathrm{~b}$ and $5 \mathrm{c}$ ), the first one corresponding to a low sedimentation rate (1,500 $\mathrm{m}$ of synrift sediments in the most distal part, i.e., $\sim 78 \mathrm{~m} / \mathrm{Myr})$ and the second to a high sedimentation rate $(5,500 \mathrm{~m}$ of synrift sediments in the most distal part, i.e., $286 \mathrm{~m} / \mathrm{Myr})$. For low sedimentation rate (Figure 5c, left panel), the temperature evolution of points $\mathrm{B}$ and $\mathrm{C}$ mimics the heat flow evolution with a maximum temperature $\left(\mathrm{B}=175^{\circ} \mathrm{C}\right.$ and $\left.\mathrm{C}=300^{\circ} \mathrm{C}\right)$ recorded when the rock undergoes the highest heat flow (i.e., at the upper- to lower-plate transition). Then, a slight decrease of the temperature occurs until the end of rifting (e.g., post-tectonic evolution of point B, Figure 5c, left panel). For high sedimentation rate (Figure 5c, right panel), the temperature is reaching a maximum value of $400^{\circ} \mathrm{C}$ for point $\mathrm{B}$ and $750{ }^{\circ} \mathrm{C}$ for point $\mathrm{C}$ when the heat flow is maximum, followed by an increase of the temperature for point B during its post-tectonic evolution. The temperature of point A shows a general increase during rifting in both the low and high sedimentation rate models.

It is important to note that, for low sedimentation rates, the temperature in the pre-rift sediments of the extensional allochthons $\mathrm{B}$ and $\mathrm{C}$ decreases during rifting despite the continuous basin infill (Figure 5c, left panel). It suggests that the decrease of the heat flow values related to the migration of the allochthons on the lower plate and to the increasing distance from the active heat source of the asthenosphere is not counterbalanced by the thermal effect of burial. For high sedimentation rates, the maximum temperature $\left(T_{\max }\right)$ at the base of the pre-rift sequence mostly increases during rifting and can eventually be overprinted by the post-tectonic thermal evolution related to burial (Figure 5c, right panel). These simplistic 1-D models suggest that $T_{\max }$ can be transported and diachronously recorded by extensional allochthons during hyperextension due to rift migration.

\section{Fossil example of Asymmetric Rift: Observations From the Arzacq-Mauléon Basin}

4.1. Geological Context

Few examples exist where the thermal record of asymmetric rifted margins can be accessed and compared to results from numerical modeling experiments. Here, we focus on an onshore fossil example of an asymmetric hyperextended rift system: the Arzacq-Mauléon basin, located in the Western Pyrenees. This basin mainly formed during Aptian to Cenomanian time as part of the Pyrenean rift system, simultaneous to the opening of the Bay of Biscay. Its southern part was subsequently inverted and integrated in the Pyrenean orogen during Late Cretaceous to Miocene convergence (Puigdefàbregas \& Souquet, 1986).

The inversion of the Arzacq-Mauléon basin as a pop-up structure (Daignières et al., 1994; Seguret, 1972) enabled the exposure of rift-related sedimentary and basement rocks and partial preservation of several 
a

b

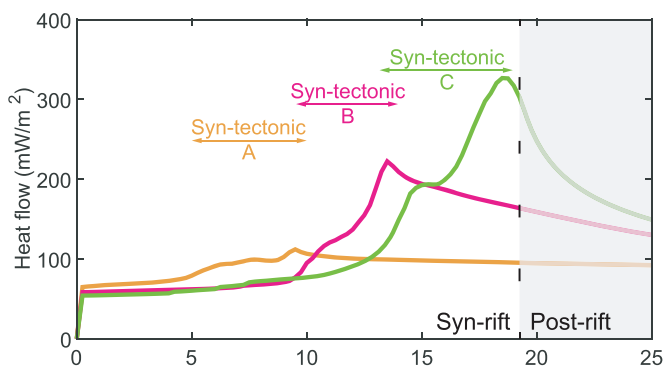

Low sedimentation rate
Model Time (My) High sedimentation rate
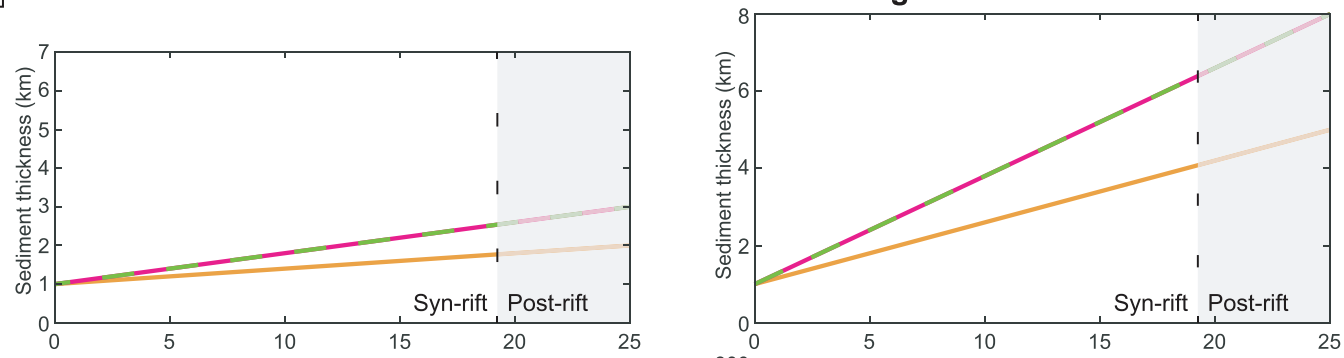

c

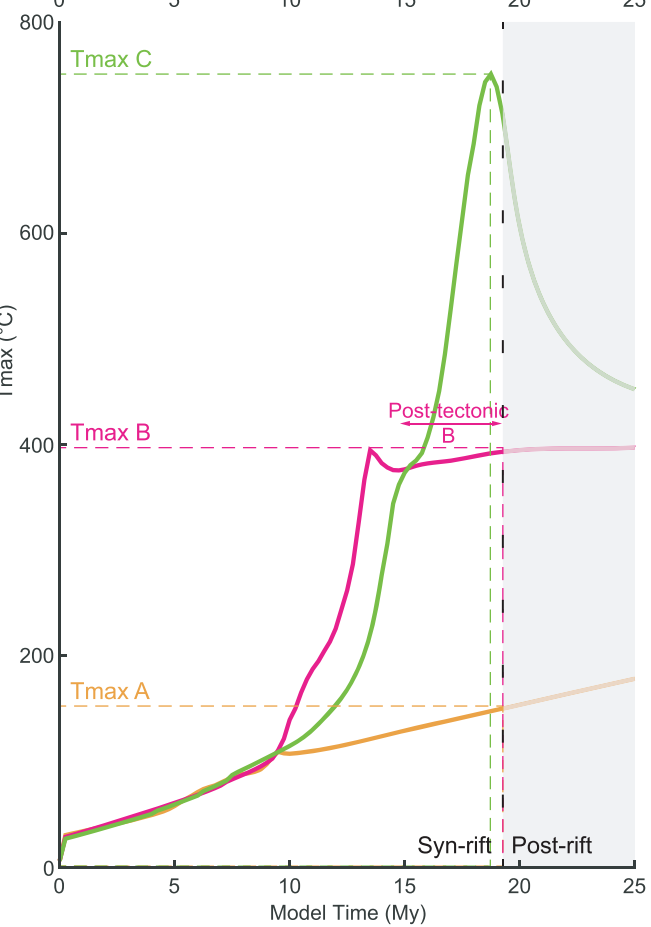

Figure 5. Temperature evolution in pre-rift sediments for two end-members of sedimentation rate. (a) Heat flow evolution for points $\mathrm{A}$, B, and C extracted from the numerical model of Figure 4. (b) Sedimentation rates assuming $1 \mathrm{~km}$ of pre-rift sediments and a lower sedimentation rate for point A due to a lower accommodation space. (c) Temperature evolution at the base of the pre-rift sedimentary cover for points A, B, and C function of rifting evolution. For low sedimentation rates, the peak temperature $\left(T_{\max }\right)$ in pre-rift sedimentary rocks can be recorded at the upper- to lower-plate transition associated with extensional allochthons. As a consequence, the $T_{\max }$ recorded by extensional allochthons is diachronous during hyperextension as exemplified by points $\mathrm{B}$ and $\mathrm{C}$ in the model. In case of high sedimentation rates, the model predicts that burial-related temperature evolution can overprint the temperature recorded at the upper- to lower-plate transition.

rift structures, allowing for the restoration of the former asymmetric rift structure (Masini et al., 2014). The southern boundary of the basin includes a series of Paleozoic massifs (Figure 6, Aldudes, Mendibelza, Igountze) that are thrust toward the south (Daignières et al., 1994; Johnson \& Hall, 1989a; Muñoz, 1992; Teixell, 1990, 1998). The Mauléon basin is bounded to the west by the Labourd massif and by the Pamplona fault zone (Claude, 1990; Jammes et al., 2009; Masini et al., 2014; Razin, 1989; Schoeffler, 1982). To the north, the Mauléon basin is thrust onto the Arzacq basin along the north vergent North Pyrenean Frontal Thrust system, consisting of the St Palais and the Ste Suzanne thrusts (Figure 6b). The 


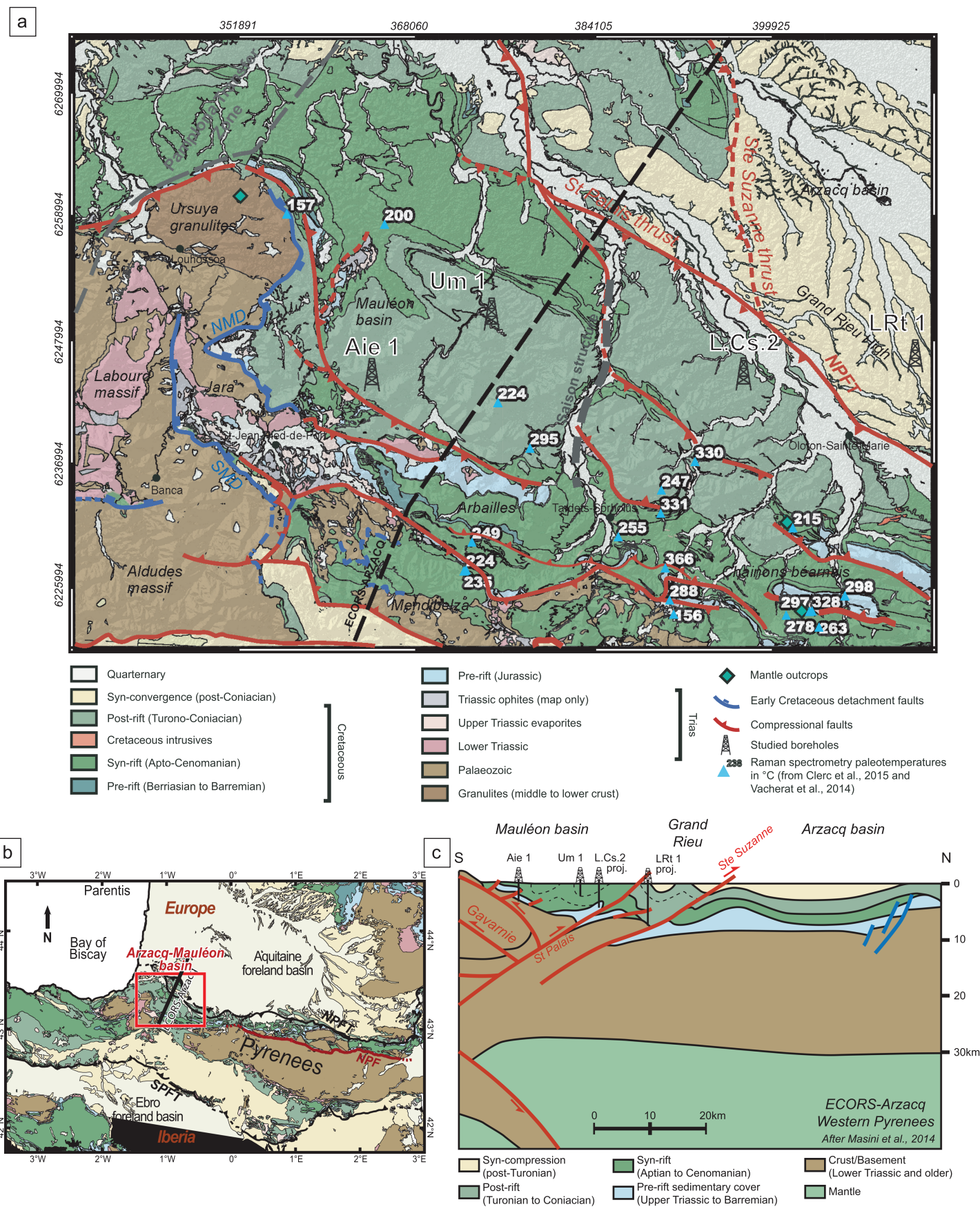

Figure 6. (a) Geological map of the Mauléon-Arzacq basin (compiled from Genna, 2007 and own observations). The locations of Raman Spectroscopy on Carbonaceous Material data $\left(T_{\max }\right)$ from subsurface rocks (Figure S4) and selected boreholes of this study are indicated. Coordinates are in meters (Lambert 93 projection). (b) Geological map of the Pyrenees with location of the study area. Coordinates are in decimal degrees (WGS84 projection). (c) Interpreted ECORS Arzacq-Western Pyrenees seismic profile, modified after Masini et al. (2014). Note that part of the pre-rift sedimentary cover is composed of the Late Triassic evaporites responsible for the thickness variation.

presence of exhumed granulites (Ursuya Massif, Figure 6) and mantle rocks in the basin are interpreted as fingerprints of extreme crustal thinning of this basin (Jammes et al., 2009; Lagabrielle et al., 2010; Lagabrielle \& Bodinier, 2008; Masini et al., 2014; Tugend et al., 2014; Tugend et al., 2015). The end of rifting was associated with an alkaline magmatic activity (Montigny et al., 1986) and a high temperature/low pressure metamorphism of Mesozoic pre-rift and early synrift sediments (Albarède \& 
Michard-Vitrac, 1978; Azambre \& Monchoux, 1998; Azambre \& Rossy, 1976; Golberg \& Maluski, 1988; Montigny et al., 1986; Thiébaut et al., 1988).

The occurrence of this rift-related high temperature/low pressure metamorphism resulted in the acquisition of an increasing amount of data aiming to investigate the rift-related thermal structure of this basin and more generally of the Pyrenean rift system (Clerc et al., 2015; Hart et al., 2017; Vacherat et al., 2014). Clerc et al. (2015) provided new constraints on peak temperatures $\left(T_{\max }\right)$ from Raman Spectroscopy on Carbonaceous Material from the Mauléon basin (Figures 6a and S4). The authors showed that relatively high temperatures in sedimentary rocks are systematically associated with the occurrence of mantle rocks and granulites. They interpreted medium to high geothermal gradients associated with mantle exhumation and a thick pre-rift (Upper Triassic to Barremian) to synrift (Apto-Cenomanian) sedimentary cover acting as a thermal blanket. Vacherat et al. (2014) and Hart et al. (2017) performed detrital zircon fission track and (U-Th-Sm)/He, and detrital zircon (U-Th)/He thermochronology, respectively, in order to define the paleothermal gradient. Their results show a thermal gradient ranging between 80 to $100{ }^{\circ} \mathrm{C} / \mathrm{km}$ for rifting in the hyperextended domain of the basin.

\subsection{Rift Evolution and Former Architecture}

Based on previous studies (e.g., Ducasse et al., 1986; Jammes et al., 2009; Johnson \& Hall, 1989b; Velasque et al., 1989) and new field data, Masini et al. (2014) argued that the Arzacq-Mauléon basin developed asymmetrically via north dipping detachment faults, implying the formation of a upper- to lower-plate architecture. Masini et al. (2014) evidenced two main detachment faults along the southern border of the Mauléon basin, referred to as the South and the North Mauléon Detachment faults (SMD and NMD, respectively; Figure 6a). They are associated with cataclasites, gouges and tectonosedimentary breccias affecting and reworking the Paleozoic basement (Figure 7). The sedimentary architecture and facies evolution from Upper Aptian to Albian sediments record the progressive creation of accommodation space. Masini et al. (2014) proposed, based on the migration of the syn-tectonic sedimentary facies tracts, a northward migration of the deformation associated with these north dipping detachment faults delimiting tilted blocks (JaraArbailles, Figure 7; see also Hart et al., 2016).

The detailed architecture of the northern Mauléon basin, interpreted as floored by the NMD, is hardly accessible due to the thick Albo-Cenomanian cover. However, Jammes et al. (2009) and Masini et al. (2014) suggested that the Labourd massif might represent the western lateral prolongation of the basement located below the northern Mauléon basin. In this area, the authors described evidence for fluid and reaction assisted brittle fault rocks and associated tectonosedimentary breccias, diagnostic of extensional detachment faults in hyperextended settings (Jammes et al., 2009; Pinto et al., 2015; Tugend et al., 2014). The description of depositional contacts between Albo-Cenomanian sediments and exhumed midcrustal granulites (Jammes et al., 2009) and the reworking of these granulites in the overlying sediments argue for laterally discontinuous and allochthonous pre-rift cover sequences separated by exhumation windows (Figure 7). These observations have been interpreted as evidence for extensional detachment faulting leading to exhumation of deeper crustal and mantle levels in the Mauléon basin (Jammes et al., 2009). The cooling ages of the footwall (i.e., Ursuya granulites, Ar/Ar on biotite: $200 \mathrm{Ma}>$ ZHe: $51 \mathrm{Ma}$; Masini et al., 2014; Vacherat et al., 2014; Hart et al., 2016) may correspond to the age of the subhorizontal synexhumation deposits of the Bonloc trough (Albo-Cenomanian). The current occurrence of a positive gravimetric anomaly in the Mauléon basin, attributed to a high-density body at shallow depth below the basin, has been interpreted by some authors (Casas et al., 1997; Chevrot et al., 2015; Jammes et al., 2010; Pedreira et al., 2007; Wang et al., 2016) as the evidence for extreme crustal thinning and likely mantle exhumation during rifting. Moreover, magmatism within Albo-Cenomanian sediments in the northern part of the Mauléon basin (Figures 6 and 8) attests for major lithospheric thinning in the hanging wall of the NMD. In summary, the overall first-order architecture of the Mauléon basin, that is, the creation of accommodation space and the exhumation of crustal and mantle rocks linked to basinward dipping faults, is compatible with a lower plate setting (Figure 2; Jammes et al., 2009;Masini et al., 2014 ; Tugend et al., 2014).

Crustal extension factors below the Arzacq basin, that is, $\beta$ factors of $\sim 2$ have been estimated from subsidence analysis (Brunet, 1984), suggesting that the crust beneath the Arzacq basin has been less thinned than the Mauléon basin (Masini et al., 2014), the latter reaching mantle exhumation. Drill holes located between 


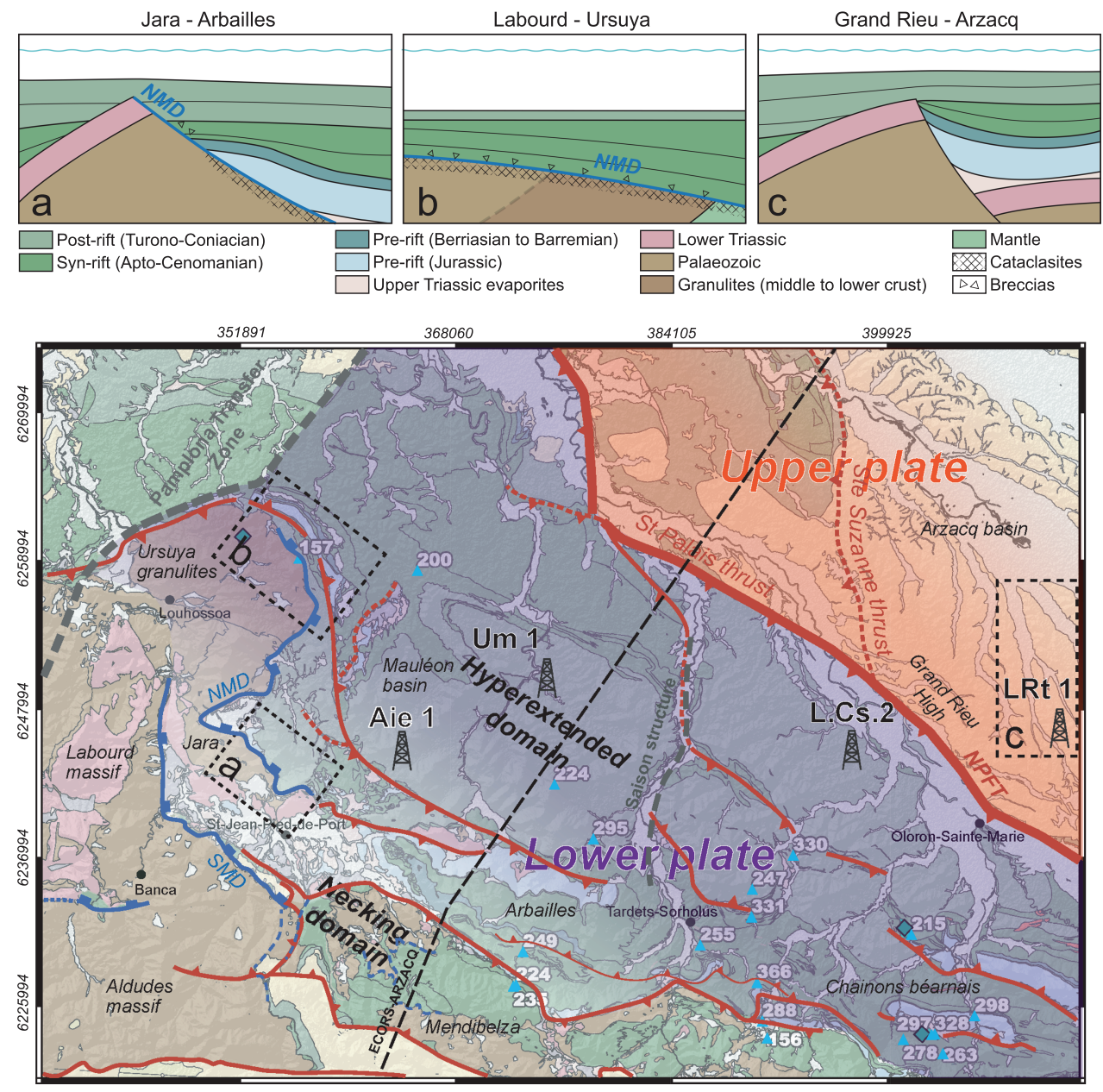

Figure 7. Key field observations, map of rift domains (after Tugend et al., 2014), and plate polarity in the inverted hyperextended Arzacq-Mauléon basin. Squares (a) and (b) correspond to key observations illustrating the main rift geometries preserved for the lower plate and square (c) for the upper plate.

the Arzacq and the Mauléon basins (e.g., Le Rouat, Figure 8) document a major unconformity between basement rocks (especially Lower Triassic sandstones) and subhorizontal, late synrift to post-rift Cretaceous sediments (Figure 7). This suggests that the Grand Rieu was a relative topographic high until late stages of rifting (Masini et al., 2014; Tugend et al., 2014) and created a topographic boundary between the Arzacq and Mauléon basins. This also reveals that the basement is not capped by a major detachment fault at this place, as it is the case for basement highs in the southern Mauléon basin (e.g., Labourd massif, Jara tilted block, Aldudes exhumed basement, Figure 6). It also points out the role of Late Triassic evaporites during mid-Cretaceous extension decoupling extension between the subevaporite and supraevaporite sedimentary cover (i.e., from Jurassic to Aptian; Jammes et al., 2010; Lagabrielle et al., 2010; Masini et al., 2014). However, the overall preservation of the pre-rift stratigraphy, together with little, observable rift deformation and minor crustal thinning suggests a typical upper plate architecture for the northern margin of the Mauléon basin (Figure 2).

\subsection{Vitrinite Reflectance Data (Proxy for $T_{\max }$ ) \\ 4.3.1. Data Set and Method}

We provide unpublished vitrinite reflectance data (courtesy of Total) from sedimentary rocks of selected boreholes from the Mauléon-Arzacq basin (Figures 8 and S5). These four boreholes are located along the dip direction with respect to the former rift orientation and provide information about the sedimentary and basement architecture of both the upper and lower plates. Thus, these boreholes can represent a 


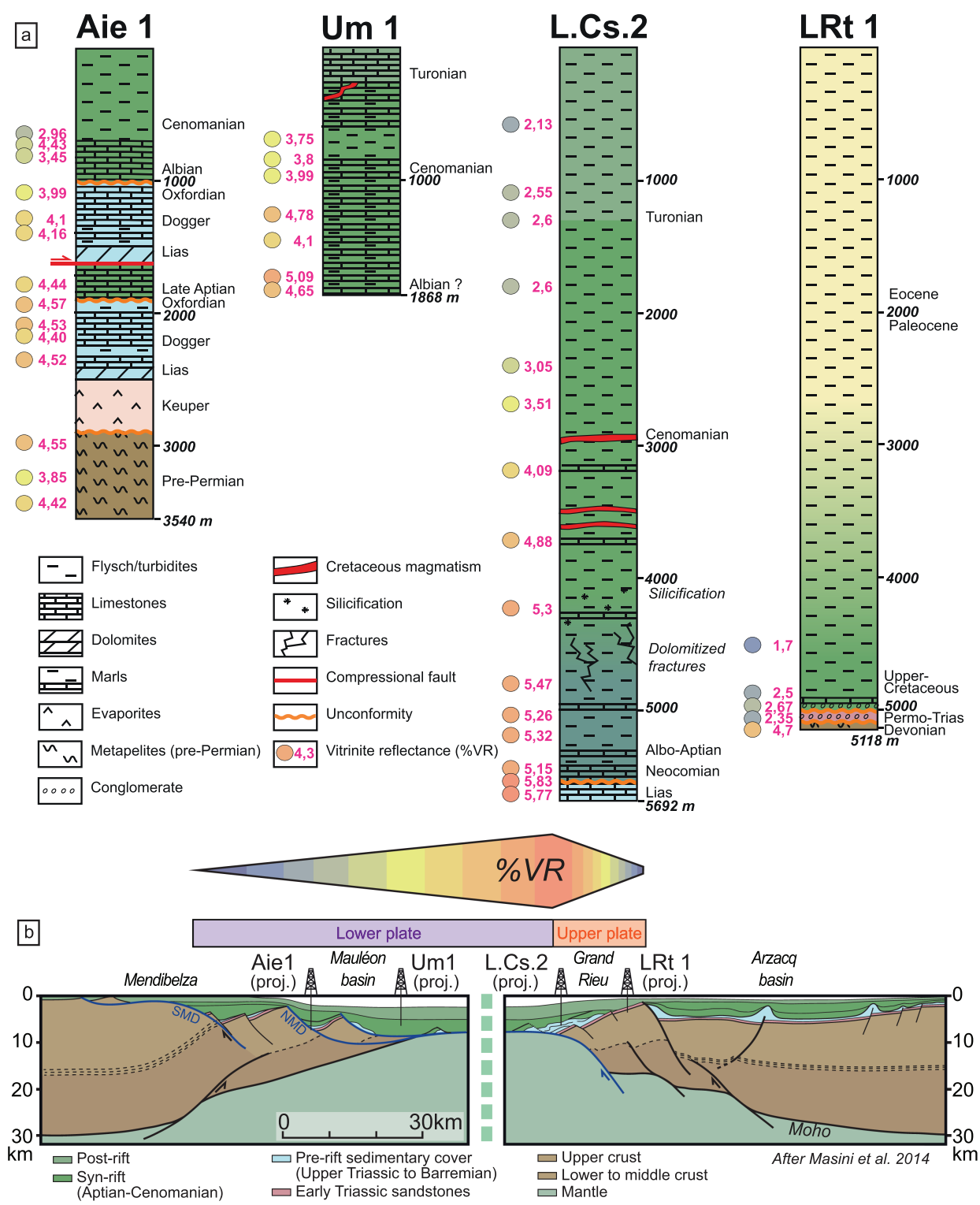

Figure 8. (a) Synthetic well logs shown for the Arzacq-Mauléon basin: Ainhice (Aie 1), Uhart-Mixe (Um 1), Les Cassières (L.Cs.2), and Le Rouat (LRt 1; location in Figure 6). See Figure S6 for $T_{\max }$ conversion. See caption in Figure 6 for the color code of sedimentary sequences. (b) Restored cross section of the Arzacq-Mauléon basin before compression (i.e., before Santonian), with approximate location of the boreholes.

section through the basin, from proximal to distal in the hyperextended domain that has not been strongly inverted during convergence and that are documenting structural levels that are not outcropping at present. The vitrinite reflectance (in \%) measures the thermal maturation of organic components. It can be used as a proxy for source rock maturation and maximum temperature history $\left(T_{\max }\right)$ of sedimentary rocks (Taylor et al., 1998). The evolution of vitrinite reflectance values (\%VR) in boreholes provides a constraint on the relative $T_{\max }$ reached by the samples within the stratigraphic log within the inverted basin. Figure 8a shows the four simplified stratigraphic logs from the Mauléon (Ainhice 1, Uhart-Mixe 1, Les Cassières 2) and Arzacq basins (Le Rouat 1). Le Rouat 1 is located on the Grand Rieu High. Wells are not significantly deviated and thus we can assume that distance corresponds, in a first approximation, to vertical depth. Although we prefer to deal with raw vitrinite reflectance data in the following to study the first-order thermal architecture of the Arzacq-Mauléon basin, we also provide the conversion of \%VR to 
$T_{\text {max }}$ based on the formulas of Barker (1988) and Barker and Pawlewicz (1994) in Table S6 so it can help compare with Raman Spectroscopy on Carbonaceous Material data of Figure 6a (also in Table S4).

4.3.2. Borehole Description

The Ainhice 1 borehole (Aie 1) shows 1,700 m of Cenomanian Flysch Noir to Lower Jurassic calcareous marls with a major erosional unconformity between the Oxfordian and the Middle-Albian. This sequence is duplicated below a thrust fault with \%VR values reaching 4,43\%VR in the Middle-Albian and $4,57 \% \mathrm{VR}$ in the Jurassic. This sequence lies onto a $400 \mathrm{~m}$ thick chaotic evaporitic layer composed of shales, evaporites, and ophites, unconformably lying above a $640 \mathrm{~m}$ thick sequence of quartzites and black shales $(4,42 \% \mathrm{VR})$ attributed to the Paleozoic, with the omission of Lower Triassic sandstones and conglomerates.

The Uhart-Mixe 1 borehole (Um 1) reaches 1,868 $\mathrm{m}$ depth. The top of the sequence is composed of Turonian limestones, less than $300 \mathrm{~m}$ thick, followed by Cenomanian to probably Albian flysch and marls at the bottom. The \%VR go from 3,75 to 5,09 with a general increase of the value with depth even though strong variations are observed within the $\log$ (Um 1 on Figure 8a).

The Les Cassières 2 borehole (L.Cs.2) penetrated down to 5,692 $\mathrm{m}$ depth. The upper part of the drill hole is composed of about 1,200 m of Turonian to Campanian flysch (shales, sandstones, and marls) with \%VR of 2,13 to 2,55. A very thick Cenomanian Flysch Noir sequence $(1,700 \mathrm{~m}$ ) is represented with the occurrence of an episyenite sill at its base. Vitrinite reflectance values range from 2,6 at the top to 3,51 at the base. The top Albian (\%VR of 4,09) is also composed of magmatic dykes. The underlying Albo-Aptian marls show evidence for an intense fluid circulation that may be responsible for the silicification of limestone beds and, toward the base, an increase of dolomitized fractures and marly beds. Available \%VR values are about 5,40\% VR. Neocomian limestones (Lower Cretaceous) display VR values of 5,15 to 5,83 and are unconformably lying over Lower Jurassic limestones (5,77\%VR).

The Le Rouat 1 borehole (LRt 1) is composed of Eocene sandstones and mudstones that overlie Upper Cretaceous marly flysch. The base of the Upper Cretaceous unit $(\sim 5,000 \mathrm{~m})$ is characterized by rounded clasts of dolostones, limestones, and red mudstones attributed to Lower Jurassic, Upper Jurassic, and PermoTriassic, respectively. This 5,000 $\mathrm{m}$ thick sequence shows a value of $2,67 \% \mathrm{VR}$ at the base. This sequence is unconformably deposited onto Permo-Triassic sandstones (2,35\%VR) that are unconformably lying onto black schists attributed to the Devonian.

\subsubsection{Results}

From south to north, we observe a deepening of the Mauléon basin associated with crustal thinning and mantle exhumation. Likewise, vitrinite reflectance (or $T_{\max }$ ) shows a downward and northward increase south of the St Palais thrust. In detail, Aie 1 shows high \%VR (3,44 to 4,44\%VR, i.e., $\sim 276$ to $303{ }^{\circ} \mathrm{C}$ according to Barker's formula) in Albo-Cenomanian and Jurassic marls and limestones, suggesting the erosion of quite thick post-rift sequences during Pyrenean convergence. Moreover, duplication of the sedimentary sequence at the base of the Early Jurassic is due to a northward thrust fault located at about 1,700 $\mathrm{m}$ and may control the overlying erosion. At the bottom of the borehole, below the Triassic Keuper, there is no evidence for the Permo-Triassic red beds. This supports the existence of an extensional contact north of the Jara block, which can be related to the NMD (Masini et al., 2014). We suggest that the heterogeneity of \%VR values in the Um 1 borehole might be related to multiple small-scale thrusts due to Pyrenean convergence. Northward, the L. Cs. 2 borehole displays intense silicification and dolomitized fractures, which attest for fluid migration in Apto-Albian sediments. It is important to note that the \%VR steadily increases from the surface to $3,200 \mathrm{~m}$ (i.e., Late Albian) and that they reach a maximum value of 5,15 to 5,83\%VR ( 331 $\left.{ }^{\circ} \mathrm{C}\right)$ from 5,000 to 5,692 $\mathrm{m}$ in the Apto-Albian to Lower Jurassic units. This \%VR trend between post-Albian (depth-dependent $\%$ VR) and pre-Albian (maximum constant \%VR) rocks has been observed in few boreholes from the Mauléon basin (e.g., Moncayolle).

On the LRt 1 borehole, in the Arzacq basin, the thick (about $5 \mathrm{~km}$ ) Late Cretaceous to Eocene sedimentary sequence displays a constant increase from top to bottom but merely reach $2,67 \% \mathrm{VR}\left(\sim 250^{\circ} \mathrm{C}\right)$. Additionally, the Permo-Triassic conglomerates reach values of $2,35 \% \mathrm{VR}$, which evidence a relative low $T_{\max }$ that has not been overprinted by the mid-Cretaceous thermal event. Thus, we can infer that the Late Cretaceous sediments did not experience significant heat flow. Interestingly, a quite high and abrupt change in \%VR is observed in the Devonian metasediments below the Triassic conglomerate, arguing for a Variscan thermal imprint. 


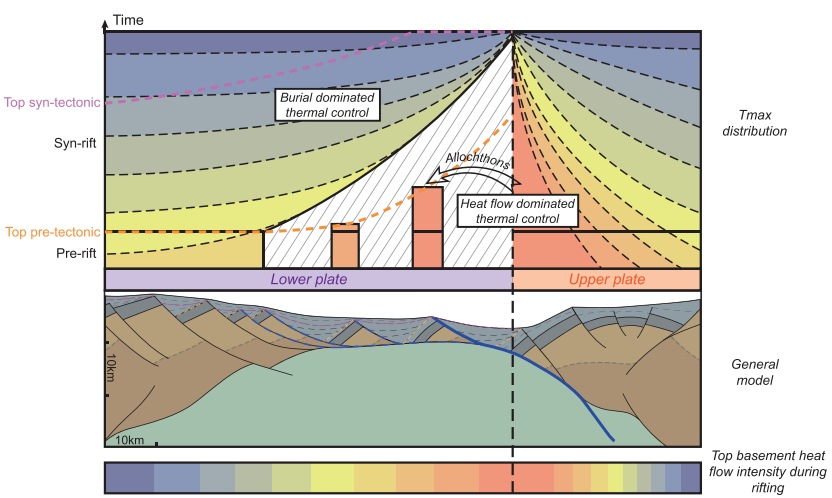

Figure 9. Figure showing conceptually the distribution of $T_{\max } /$ heat flow as a function of the extensional evolution in an asymmetric rift system. Warm colors represent relative high $T_{\max }$ or high heat flow, while cold colors represent low $T_{\max }$ or heat flow. The horizontal gradient at the bottom of the figure represents a theoretical maximum basal heat flow distribution during hyperextension (based on the numerical model shown in Figure 3). (top) Theoretical $T_{\max }$ distribution onto the typical Wheeler diagram for hyperextended domains at late synrift (see Figure 2). The general asymmetry in the distribution of $T_{\max }$ between the lower and the upper plate is represented. We suggest a steep horizontal $T_{\max }$ gradient on the upper plate due to the rapid crustal thinning and the proximity to the active exhumation zone, where the maximum heat flow and temperatures are located (see Figures 3 and 5). Highest $T_{\max }$ are recorded at the upper-lower plate transition (Figure 5). Blocks originating from the upper plate and transported as extensional allochthon blocks onto the lower plate represent $T_{\max }$ anomalies. While the pre-tectonic sequence shows asymmetric and diachronous peak heat events controlled by the asymmetric basal heat flow, the syn-tectonic to post-tectonic sediments are in addition also controlled by burial.

Thus, the main signal investigated in this study is recorded in the basal, pretectonic to syn-tectonic sequence of the hyperextended basin.
These observations evidence a progressive deepening of the Mauléon basin from south to north as expected for a lower plate, associated with a general increase of $T_{\max }$ (in this study $\% \mathrm{VR}$ ) and first occurrence of magmatism. The highest $T_{\max }$ are observed at the transition between the lower plate and the upper plate (Figures 8b and S6, L.Cs.2 borehole). North of the St Palais thrust (i.e., upper plate), the rift-related crustal thickness abruptly changes and the recorded $T_{\max }$ are very low in the synrift to post-rift sediments (LRt 1 borehole). This structural and thermal relationship points to a general asymmetry of the Arzacq-Mauléon rift system that is not consistent with symmetrical rifting.

\section{Discussion}

\subsection{First-Order Rift-Related Thermal Structure and Evolution of} Hyperextended Systems

\subsubsection{Thermal Asymmetry}

The numerical model shows that in relation to asymmetric rift evolution, the maximum heat flow location at the base of the basin increases during hyperextension and tends to migrate toward and to stabilize over the upper- to lower-plate transition (Figure 3). This results in a higher horizontal thermal gradient on the upper plate than on the lower plate (Figure 9). Interestingly, the heat flow evolution of asymmetric hyperextended rifts does not strictly correlate with crustal thinning as, for a similar crustal thickness, various heat flow values can be observed. In that sense, this evolution cannot be accounted for using depth uniform models (e.g., McKenzie, 1978).

In the Arzacq-Mauléon basin, the asymmetry is also expressed in the distribution of $T_{\max }$, once restored back into their former rift context (Figure $8 \mathrm{~b}$ ). The highest $T_{\max }$ values were located at the inferred upperto lower-plate transition, associated with deep crustal and mantle rocks. They were later transported during convergence onto the upper plate along the St Palais thrust and juxtaposed to sediments showing lower $T_{\max }$ values.

Both the numerical model and field observations show an asymmetric heat distribution with respect to the upper- to lower-plate transition (Figures 3, 8 b and 9). This strongly suggests a relationship between rift asymmetry and thermal asymmetry that cannot be explained by pure shear depth uniform thinning. This asymmetric evolution during rifting may be applicable to the heat flow evolution of other asymmetric magmapoor rift systems such as the Parentis basin (Jammes, Tiberi, \& Manatschal, 2010), the NewfoundlandIberia conjugate margins, the Labrador Sea, the Porcupine Basin (Figure 1), the Central South Atlantic magma-poor segments (Péron-Pinvidic et al., 2017), the Australia-Antarctica margins (Direen et al., 2013), the Australian North West Shelf (Karner \& Driscoll, 1999), or the East Australia-Lord Howe rise conjugates (Gaina et al., 1998).

\subsubsection{Formation of Extensional Allochthons, Role of Sedimentation and $\boldsymbol{T}_{\max }$ Distribution}

The numerical model shows that top basement rocks are submitted to locally very high heat flow, especially at the tip of the upper plate (Figure 3). In low sedimentation rate settings, 1-D thermal models (Figure 5c) demonstrate that pre-tectonic rocks can record their highest temperature $\left(T_{\max }\right)$ at the upper- to lower-plate transition. Due to their position, they can become part of the lower plate (e.g., allochthon formation) at any time (Figure 3). Once they are transported on the lower plate where heat flow decreases, they are submitted to temperatures that are lower than the $T_{\max }$ recorded at the upper- to lower-plate transition (Figure $5 \mathrm{c}$, left panel). This results in a thermal event recorded in the pre-tectonic sediments controlled by the basal heat flow that is diachronous and short-lived (Figures 5 and 9).

Syn-tectonic to post-tectonic (synrift) sediments that seal the extensional allochthons can be deposited under conditions with lower heat flow values once on the lower plate (Figures 3 and 5). They can therefore record $T_{\max }$ values that are mainly controlled by the sedimentary thickness (burial dominated; Figures 9 and 10). 


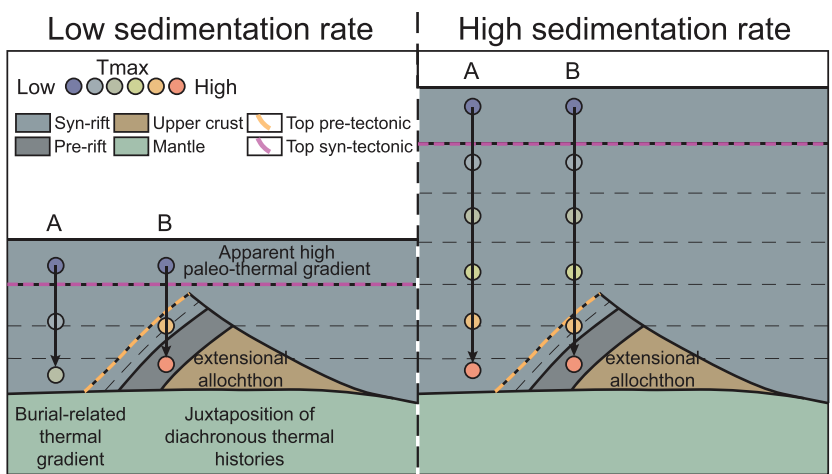

Figure 10. Role of sedimentation rates on the thermal architecture of hyperextended domains at the end of rifting. In low sedimentation rates, $T_{\max }$ in the pre-tectonic sediments (extensional allochthon) have been recorded at the upper- to lower-plate transition and transported onto the lower plate.

$T_{\max }$ within the syn-tectonic to post-tectonic sediments are diachronous and depend on sedimentation rate (burial) during hyperextension. Gradient A shows a typical burial-related thermal gradient under moderate heat flow on the lower plate (late rifting). Gradient B juxtaposes two diachronous thermal histories. In low sedimentation rate systems, the determination of the paleothermal gradient using $T_{\max }$ can be misleading. In high sedimentation rate systems, the burial thermal history can overprint the former thermal event and $T_{\max }$ can be synchronously recorded at the end of rifting throughout the rift basin.
This second thermal event is regional (at the basin scale) and lasts longer. $T_{\max }$ from these two thermal events can be juxtaposed on the lower plate between the extensional allochthon and the overlaying sedimentary sequence and can potentially result in very sharp limits between high and low $T_{\max }$ values occurring over short distances (Figures 9 and 10). As a consequence, paleothermal gradients determined from such data sets might provide unrealistic values and lead to the overestimation of the background heat flow at the base of the basin (Figure 10).

In case of high sedimentation rates, the burial related thermal event can eventually overprint or obliterate the former thermal event due to the basal heat flow (Figure 5c, right panel and Figure 10). As such, the synrift thermal architecture will be controlled by the burial history and $T_{\max }$ will be mostly synchronously recorded at the end of hyperextension throughout the basin.

To summarize, sedimentation can either reveal, obliterate or overprint these diachronous thermal events (heat flow vs. burial dominated) related to rift migration. However, further works integrating complex thermal models of basins and realistic sedimentary infill evolution will be necessary to investigate these extreme cases.

\subsection{Implications and Limitations Derived From the Pyrenean Case}

New vitrinite reflectance data from the Arzacq-Mauléon basin show an asymmetry of the $T_{\max }$ distribution within the pre-rift to synrift sequences of the basin, likely due to asymmetric heat flow evolution associated with northward migration of the north dipping Mauléon detachment faults (Masini et al., 2014). Despite a well constrained metamorphic zone (NPMZ) in the eastern Pyrenees and in the Basque-Cantabrian basin, its continuation in the Mauléon basin was questioned (Albarède \& Michard-Vitrac, 1978; Golberg \& Leyreloup, 1990). Based on this new thermal data set derived from boreholes, we can suggest that the so-called NPMZ and consequently rocks with highest $T_{\max }$ are not exposed but are buried deeper in the northern part of the Mauléon basin.

In order to compare the $T_{\max }$ measured in the asymmetric Arzacq-Mauléon basin with the thermal data extracted from our numerical model, we combined the heat flow evolution from the model and the synrift sedimentary thicknesses defined in the Mauléon boreholes to calculate the theoretical $T_{\max }$ in the pre-rift sediments (Figure 11). Results suggest $T_{\max }$ values ranging from 200 to $490{ }^{\circ} \mathrm{C}$ depending on the maturity of hyperextension and are in accordance with $T_{\max }$ from pre-rift sediments of the Mauléon basin ranging from 288 to $330^{\circ} \mathrm{C}$ (Figures S4 and S6). Our generic model of asymmetric rifting can explain the first-order thermal evolution of Arzacq-Mauléon basin, even if thermal blanketing and fluid circulation are not taken into account and might have played a role in the distribution of $T_{\max }$ in the North Pyrenean basins (e.g., Boulvais, 2016; Clerc et al., 2015).

Although we demonstrate a structural and thermal asymmetry of the Arzacq-Mauléon rift system similar to the numerical model, the complexity raised by the presence of allochthons has not been evidenced in our study area. We suggest that gravity gliding and migration of the pre-rift sedimentary cover on Upper Triassic evaporites might result in additional complexity to the tectonic and thermal history. Such a process has been recently proposed and discussed by Duretz et al. (2019) based on a numerical model and the observations from the eastern Pyrenees. However, our field observations and the existing data set are not able to resolve the impact of such an allochthony on the thermal architecture of the basin.

\section{3. $T_{\max }$, Thermal Gradient and Heat Flow: General Implications}

Thermal parameters such as $T_{\max }$, thermal gradient and heat flow are commonly used to define the thermal state of rift basins with the assumption that crustal thinning and radiogenic heat production are the main controlling factors (e.g., McKenzie model). However, data from numerical models imply a more complex architecture, where allochthonous structural units and diachronous thermal events can be observed on a single vertical section. 

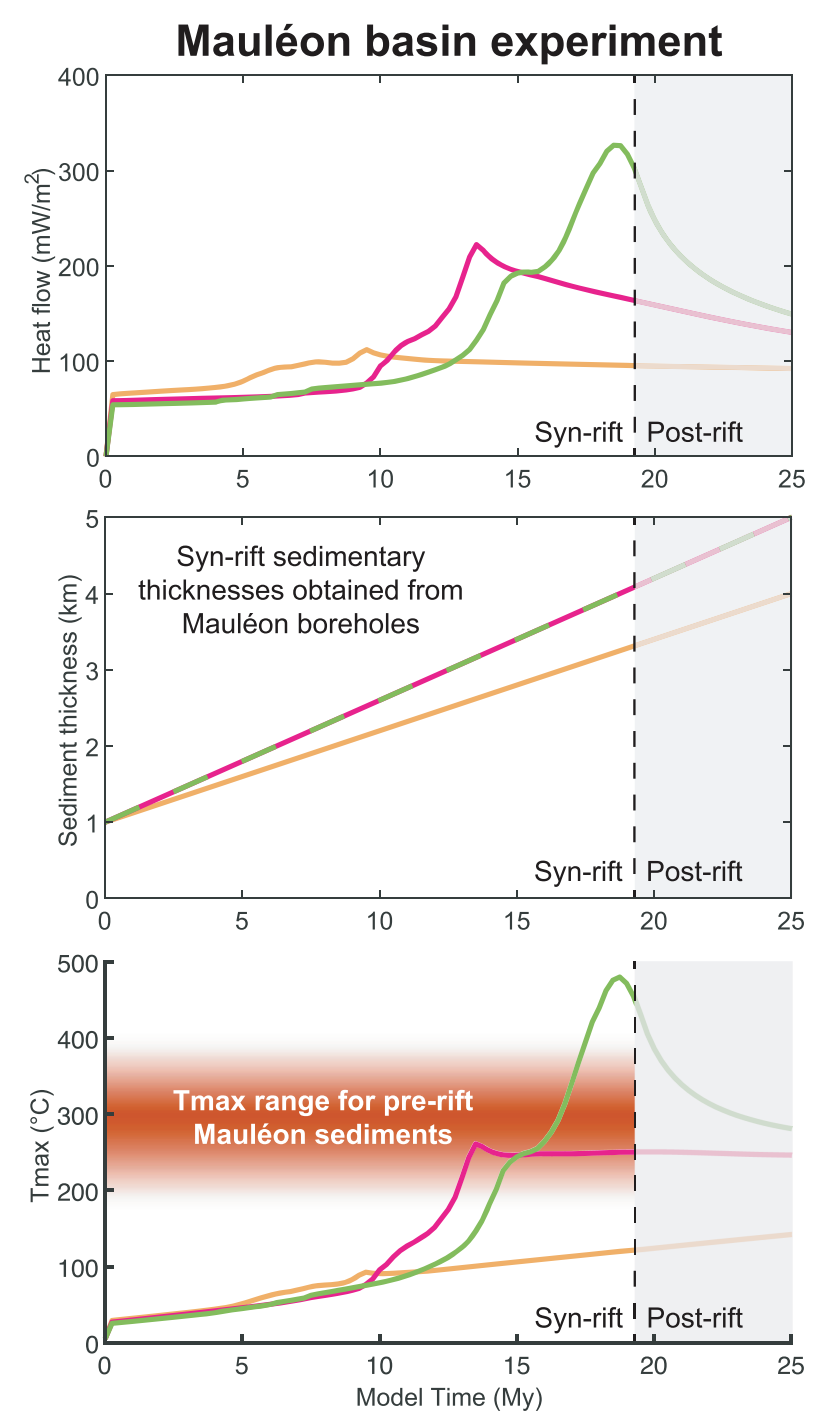

Figure 11. Theoretical 1-D thermal model of the Mauléon basin based on heat flow values from the numerical model. See the similarities between measured $T_{\max }$ values based on the heat flow values of the numerical model and the $T_{\max }$ converted from the Mauléon boreholes and from subsurface Raman Spectroscopy on Carbonaceous Material measurements $\left(\sim 30{ }^{\circ} \mathrm{C}\right.$, see Table S4 and Figure S6). Conductivity, radiogenic heat production and surface temperature are identical to the 1-D thermal models of Figure 5.
Indeed, the thermal gradient and top basement heat flow values are increasing during rifting but their locations vary due to rift migration. Especially in asymmetrical hyperextended rift basins, a strong variation of the thermal gradient from the lower to the upper plate must be expected. Moreover, this first-order thermal structure can be modified by fluid circulation (Boulvais, 2016; Person et al., 1996; Souche et al., 2014) or magmatic additions at various time leading to local perturbations of the $T_{\max }$ values. Type and rate of sedimentation can also affect the surface and top basement heat flow, such as evidenced by the thermal blanketing effect (e.g., Hutchison, 1985; Souche et al., 2017). However, in systems with low sedimentation rates, the top basement heat flow can slightly decrease with respect to models without sedimentation (e.g., Souche et al., 2017; Theissen \& Rüpke, 2009) but follows a trend that is similar to our model (Figures 4 and S2). In this study, we only investigated the synrift thermal evolution based on simplistic 1-D thermal models of basin. Further studies should be undertaken considering the entire rifting evolution and taking into account fluids, sedimentation rates and synrift to post-rift magmatic activity.

$T_{\max }$ is commonly used to constrain paleothermal gradients and the thermal architecture of fossil rift basins. However, our analysis highlights that the maximum temperature recorded by a rock does not reflect the complete thermal history of the rock and is hence prone to misinterpretations (Figure 10). This is exemplified in the diachronous tectonic and thermal histories of our study, where rocks with $T_{\max }$ acquired at different moments and in different thermal contexts have been juxtaposed (see Figures 9 and 10). The resulting paleothermal gradient extracted with these two values might be unrealistically high and does not represent a real paleothermal gradient at any time of the rift evolution.

We propose that the thermal asymmetry observed in pre-rift to synrift sequences is a good indicator to define the polarity (upper vs. lower plate) of hyperextended rift systems. Moreover, abrupt changes of $T_{\max }$ values could suggest the occurrence of an allochthonous extensional unit on top of a detachment fault in a lower plate setting.

\section{Conclusions}

Both numerical model and field study show a thermal asymmetry with the maximum heat flow and the highest $T_{\max }$ located at the upper- to lowerplate transition. Modeling results also highlight a strong diachronism in the record of the maximum heat flow and $T_{\max }$ for each extensional allochthon in hyperextended domains. These results might also apply to present-day asymmetric, hyperextended magma-poor rifted margins.

We suggest that the peak heat in sedimentary rift basins is controlled by the relative importance of two processes:

- A local and short-lived thermal event located above the focus of hot asthenospheric upwelling at the upper- to lower-plate transition that leads to very high heat flow, which is likely amplified by fluid circulation. Upper plate blocks made of pre-tectonic material recording very high $T_{\text {max }}$ values might be transferred during rift migration from the upper to the lower plate. Once this transfer is completed, heat flow within these blocks is rapidly decreasing as the upper- to lower-plate transition migrates further away.

- A regional event affecting the entire basin and related to basin infill and burial. The resulting thermal gradient in these sediments notably depends on the timing and rate of sedimentation, the lithology and the basal heat flow. 
Both thermal events can be juxtaposed on the lower plate after the formation of allochthons and may lead to unrealistic or not representative paleothermal gradients in case of low sedimentation rates. Such a diachronous and asymmetric evolution of the thermal parameters ( $T_{\max }$, heat flow, and thermal gradient) in asymmetric rift systems leads to a complex final thermal architecture that cannot be understood through depth uniform models or extrapolation of 1-D $T_{\max }$ values.

\section{Acknowledgments}

We thank three anonymous reviewers and the Associate Editor for their constructive comments, which helped to improve the paper. We thank Total for providing us with the vitrinite reflectance data, M. Nirrengarten for helpful information on this topic, and $\mathrm{P}$. Le Maire for the help with 1-D models. All the data used are listed in the references, in the supporting information, and are available on the 4TU.ResearchData repository (http:// doi.org/10.4121/uuid:9d6179b1-b79241bf-a92f-22c7f47da4a5). Raw data results from the numerical model are available at this site (http://doi.org/ 10.4121/uuid:12c88870-392d-40d7b33d-5a9e934482e8). This study was funded by the Orogen project, a tripartite joint academic-industry research program between the CNRS, BRGM, and Total R\&D Frontier Exploration program. J. T. was funded through the MM4 consortium. S. B. was funded through the Helmholtz Young Investigators Group CRYSTALS (VHNG-1132). Supporting information related to this article is included as three tables (S1, S4, and S6), three figures (S2, $\mathrm{S} 5$, and S6) and one movie (S3).

\section{References}

Albarède, F., \& Michard-Vitrac, A. (1978). Age and significance of the North Pyrenean metamorphism. Earth and Planetary Science Letters, 40(3), 327-332. https://doi.org/10.1016/0012-821X(78)90157-7

Alves, T. M., Moita, C., Cunha, T., Ullnaess, M., Myklebust, R., Monteiro, J. H., \& Manuppella, G. (2009). Diachronous evolution of Late Jurassic-Cretaceous continental rifting in the northeast Atlantic (west Iberian margin). Tectonics, 28, TC4003. https://doi.org/10.1029/ 2008TC002337

Autin, J., Leroy, S., Beslier, M. O., d'Acremont, E., Razin, P., Ribodetti, A., et al. (2010). Continental break-up history of a deep magma-poor margin based on seismic reflection data (northeastern Gulf of Aden margin, offshore Oman). Geophysical Journal International, 180(2), 501-519. https://doi.org/10.1111/j.1365-246X.2009.04424.x

Azambre, B., \& Monchoux, P. (1998). Métagabbros amphiboliques et mise en place crustale des lherzolites des Pyrénées (France). Comptes Rendus de l'Académie Des Sciences - Series IIA - Earth and Planetary Science, 327(1), 9-15. https://doi.org/10.1016/S1251-8050(98)80012-8

Azambre, B., \& Rossy, M. (1976). Le magmatisme alcalin d'age cretace, dans les Pyrenees occidentales et l'Arc basque; ses relations avec le metamorphisme et la tectonique. Bulletin de La Societe Geologique de France, S7-XVIII(6), 1725. https://doi.org/10.2113/ gssgfbullS7XVIII61725

Barker, C. E. (1988). Geothermics of petroleum systems: Implications of the stabilization of kerogen thermal maturation after a geologically brief heating duration at peak temperature. In Petroleum Systems of the United States, US Geological Survey Bulletin 1870 (Vol. 1870 , pp. 26-29). Washington, DC.

Barker, C. E., \& Pawlewicz, M. J. (1994). Calculation of vitrinite reflectance from thermal histories and peak temperatures: A comparison of methods. In P. K. Mukhopadhyay, \& W. G. Dow (Eds.), Vitrinite Reflectance as a Maturity Parameter (Vol. 570, pp. 216-229). Washington, DC: American Chemical Society. https://doi.org/10.1021/bk-1994-0570.ch014

Beltrando, M., Stockli, D. F., Decarlis, A., \& Manatschal, G. (2015). A crustal-scale view at rift localization along the fossil Adriatic margin of the Alpine Tethys preserved in NW Italy. Tectonics, 34, 1927-1951. https://doi.org/10.1002/2015TC003973

Blaich, O. A., Faleide, J. I., \& Tsikalas, F. (2011). Crustal breakup and continent-ocean transition at South Atlantic conjugate margins. Journal of Geophysical Research, 116, B01402. https://doi.org/10.1029/2010JB007686

Boulvais, P. (2016). Fluid generation in the Boucheville Basin as a consequence of the North Pyrenean metamorphism. From Rifting to Mountain Building: The Pyrenean Belt, 348(3), 301-311. https://doi.org/10.1016/j.crte.2015.06.013

Brune, S. (2014). Evolution of stress and fault patterns in oblique rift systems: 3-D numerical lithospheric-scale experiments from rift to breakup. Geochemistry, Geophysics, Geosystems, 15, 3392-3415. https://doi.org/10.1002/2014GC005446

Brune, S., Heine, C., Pérez-Gussinyé, M., \& Sobolev, S. V. (2014). Rift migration explains continental margin asymmetry and crustal hyperextension. Nature Communications, 5(4014). https://doi.org/10.1038/ncomms5014

Brune, S., Heine, C., Clift, P. D., \& Pérez-Gussinyé, M. (2017). Rifted margin architecture and crustal rheology: Reviewing IberiaNewfoundland, Central South Atlantic, and South China Sea. Marine and Petroleum Geology, 79, 257-281. https://doi.org/10.1016/j. marpetgeo.2016.10.018

Brune, S., Popov, A. A., \& Sobolev, S. V. (2012). Modeling suggests that oblique extension facilitates rifting and continental break-up. Journal of Geophysical Research, 117, B08402. https://doi.org/10.1029/2011JB008860

Brune, S., Popov, A. A., \& Sobolev, S. V. (2013). Quantifying the thermo-mechanical impact of plume arrival on continental break-up. Progress in Understanding the South Atlantic Margins, 604, 51-59. https://doi.org/10.1016/j.tecto.2013.02.009

Brune, S., Williams, S. E., Butterworth, N. P., \& Müller, R. D. (2016). Abrupt plate accelerations shape rifted continental margins. Nature, 536, 201.

Brunet, M.-F. (1984). Subsidence history of the Aquitaine basin determined from subsidence curves. Geological Magazine, 121(5), 421-428.

Casas, A., Kearey, P., Rivero, L., \& Adam, C. R. (1997). Gravity anomaly map of the Pyrenean region and a comparison of the deep geological structure of the western and eastern Pyrenees. Earth and Planetary Science Letters, 150(1), 65-78. https://doi.org/10.1016/S0012-821X(97)00087-3

Chelalou, R., Nalpas, T., Bousquet, R., Prevost, M., Lahfid, A., Poujol, M., et al. (2016). New sedimentological, structural and paleothermicity data in the Boucheville Basin (eastern North Pyrenean Zone, France). From Rifting to Mountain Building: The Pyrenean Belt, 348(3-4), 312-321. https://doi.org/10.1016/j.crte.2015.11.008

Chevrot, S., Sylvander, M., Diaz, J., Ruiz, M., Paul, A., \& Group, the P. W (2015). The Pyrenean architecture as revealed by teleseismic $P$-to- $S$ converted waves recorded along two dense transects. Geophysical Journal International, 200(2), 1096-1107. https://doi.org/10.1093/gji/ ggu400

Chian, D., Louden, K. E., \& Reid, I. (1995). Crustal structure of the Labrador Sea conjugate margin and implications for the formation of nonvolcanic continental margins. Journal of Geophysical Research, 100(B12), 24,239-24,253.

Claude, D. (1990). Etude stratigraphique, sédimentologique et structurale des dépôts mésozoïques au nord du massif du Labourd: rôle de la faille de Pamplona, Pays Basque.

Clerc, C., Lagabrielle, Y., Labaume, P., Ringenbach, J.-C., Vauchez, A., Nalpas, T., et al. (2016). Basement-Cover decoupling and progressive exhumation of metamorphic sediments at hot rifted margin. Insights from the Northeastern Pyrenean analog. Tectonophysics, 686 (Supplement C), 82-97. https://doi.org/10.1016/j.tecto.2016.07.022

Clerc, C., Lahfid, A., Monié, P., Lagabrielle, Y., Chopin, C., Poujol, M., et al. (2015). High-temperature metamorphism during extreme thinning of the continental crust: A reappraisal of the North Pyrenean passive paleomargin. Solid Earth, 6(2), 643-668. https://doi.org/ 10.5194/se-6-643-2015

Clift, P. D., Brune, S., \& Quinteros, J. (2015). Climate changes control offshore crustal structure at South China Sea continental margin. Earth and Planetary Science Letters, 420(Supplement C), 66-72. https://doi.org/10.1016/j.epsl.2015.03.032

Daignières, M., Séguret, M., \& Specht, M. (1994). The Arzacq-Western Pyrenees ECORS deep seismic profile. In A. Mascle (Ed.), Hydrocarbon and petroleum geology of France (pp. 199-208). Berlin, Heidelberg: Springer Berlin Heidelberg. https://doi.org/10.1007/9783-642-78849-9_15 
Díaz, J., \& Gallart, J. (2009). Crustal structure beneath the Iberian Peninsula and surrounding waters: A new compilation of deep seismic sounding results. Physics of the Earth and Planetary Interiors, 173(1), 181-190. https://doi.org/10.1016/j.pepi.2008.11.008

Direen, N. G., Stagg, H. M. J., Symonds, P. A., \& Norton, I. O. (2013). Variations in rift symmetry: cautionary examples from the Southern Rift System (Australia-Antarctica). Geological Society, London, Special Publications, 369(1), 453-475. https://doi.org/10.1144/SP369.4

Ducasse, L., Velasque, P.-C., \& Muller, J. (1986). Glissement de couverture et panneaux basculés dans la région des Arbailles (Pyrénées occidentales): Un modèle évolutif crétacé de la marge nord-ibérique à l'Est de la transformante de Pamplona. Comptes Rendus de l'Académie Des Sciences. Série 2, Mécanique, Physique, Chimie, Sciences de l'univers, Sciences de La Terre, 303(16), 1477-1482.

Duretz, T., Asti, R., Lagabrielle, Y., Brun, J., Jourdon, A., Clerc, C., \& Corre, B. (2019). Numerical modelling of Cretaceous Pyrenean Rifting: The interaction between mantle exhumation and syn-rift salt tectonics. Basin Research. https://doi.org/10.1111/bre.12389

Duretz, T., Petri, B., Mohn, G., Schmalholz, S. M., Schenker, F. L., \& Müntener, O. (2016). The importance of structural softening for the evolution and architecture of passive margins. Scientific Reports, 6. https://doi.org/10.1038/srep38704

Espurt, N., Callot, J.-P., Roure, F., Totterdell, J. M., Struckmeyer, H. I. M., \& Vially, R. (2012). Transition from symmetry to asymmetry during continental rifting: an example from the Bight Basin-Terre Adélie (Australian and Antarctic conjugate margins). Terra Nova, 24(3), 167-180. https://doi.org/10.1111/j.1365-3121.2011.01055.x

Frasca, G., Gueydan, F., Brun, J.-P., \& Monié, P. (2016). Deformation mechanisms in a continental rift up to mantle exhumation. Field evidence from the western Betics, Spain. Marine and Petroleum Geology, 76(Supplement C), 310-328. https://doi.org/10.1016/j. marpetgeo.2016.04.020

Gaina, C., Müller, D. R., Royer, J.-Y., Stock, J., Hardebeck, J., \& Symonds, P. (1998). The tectonic history of the Tasman Sea: A puzzle with 13 pieces. Journal of Geophysical Research, 103(B6), 12,413-12,433. https://doi.org/10.1029/98JB00386

Genna, A. (2007). Carte géologique harmonisée au 1/50 000 du département des Pyrénées-Atlantiques, (BRGM/RP-55408-FR).

Gerya, T. (2019). Introduction to numerical geodynamic modelling (Vol. 2). Cambridge University Press.

Gillard, M., Autin, J., \& Manatschal, G. (2016). Fault systems at hyper-extended rifted margins and embryonic oceanic crust: Structural style, evolution and relation to magma. Marine and Petroleum Geology, 76, 51-67. https://doi.org/10.1016/j.marpetgeo.2016.05.013

Gleason, G. C., \& Tullis, J. (1995). A flow law for dislocation creep of quartz aggregates determined with the molten salt cell. Tectonophysics, 247(1), 1-23. https://doi.org/10.1016/0040-1951(95)00011-B

Golberg, J. M., \& Leyreloup, A. F. (1990). High temperature-low pressure Cretaceous metamorphism related to crustal thinning (Eastern North Pyrenean Zone, France). Contributions to Mineralogy and Petrology, 104(2), 194-207. https://doi.org/10.1007/bf00306443

Golberg, J.-M., \& Maluski, H. (1988). Données nouvelles et mise au point sur l'âge du métamorphisme pyrénéen. Comptes Rendus de l'Académie Des Sciences. Série 2, Mécanique, Physique, Chimie, Sciences de l'univers. Sciences de La Terre, 306(6), 429-435.

Hart, N. R., Stockli, D. F., \& Hayman, N. W. (2016). Provenance evolution during progressive rifting and hyperextension using bedrock and detrital zircon U-Pb geochronology, Mauléon Basin, western Pyrenees. Geosphere, 12(4), 1166-1186. https://doi.org/ 10.1130/GES01273.1

Hart, N. R., Stockli, D. F., Lavier, L. L., \& Hayman, N. W. (2017). Thermal evolution of a hyperextended rift basin, Mauléon Basin, western Pyrenees. Tectonics, 36, 1103-1128. https://doi.org/10.1002/2016TC004365

Haupert, I., Manatschal, G., Decarlis, A., \& Unternehr, P. (2016). Upper-plate magma-poor rifted margins: Stratigraphic architecture and structural evolution. Marine and Petroleum Geology, 69(Supplement C), 241-261. https://doi.org/10.1016/j.marpetgeo.2015.10.020

Hirth, G., \& Kohlstedt, D. (2003). Rheology of the upper mantle and the mantle wedge: A view from the experimentalists. In J. Eiler (Ed.), Geophysical Monograph Series (Vol. 138, pp. 83-105). Washington, DC: American Geophysical Union. https://doi.org/10.1029/138GM06

Huismans, R. S., \& Beaumont, C. (2002). Asymmetric lithospheric extension: The role of frictional plastic strain softening inferred from numerical experiments. Geology, 30(3), 211-214. https://doi.org/10.1130/0091-7613(2002)030<0211:ALETRO>2.0.CO;2

Huismans, R. S., \& Beaumont, C. (2003). Symmetric and asymmetric lithospheric extension: Relative effects of frictional-plastic and viscous strain softening: symmetric and asymmetric extension. Journal of Geophysical Research, 108(B10), 2496. https://doi.org/10.1029/ 2002JB002026

Huismans, R. S., \& Beaumont, C. (2014). Rifted continental margins: The case for depth-dependent extension. Earth and Planetary Science Letters, 407(Supplement C), 148-162. https://doi.org/10.1016/j.epsl.2014.09.032

Hutchison, I. (1985). The effects of sedimentation and compaction on oceanic heat flow. Geophysical Journal International, 82(3), 439-459. https://doi.org/10.1111/j.1365-246X.1985.tb05145.x

Jammes, S., \& Lavier, L. L. (2016). The effect of bimineralic composition on extensional processes at lithospheric scale. Geochemistry, Geophysics, Geosystems, 17, 3375-3392. https://doi.org/10.1002/2016GC006399

Jammes, S., Manatschal, G., \& Lavier, L. (2010). Interaction between prerift salt and detachment faulting in hyperextended rift systems: The example of the Parentis and Mauléon basins (Bay of Biscay and western Pyrenees). AAPG Bulletin, 94(7), 957-975. https://doi.org/ $10.1306 / 12090909116$

Jammes, S., Manatschal, G., Lavier, L., \& Masini, E. (2009). Tectonosedimentary evolution related to extreme crustal thinning ahead of a propagating ocean: Example of the western Pyrenees. Tectonics, 28(4), TC4012. https://doi.org/10.1029/2008TC002406

Jammes, S., Tiberi, C., \& Manatschal, G. (2010). 3D architecture of a complex transcurrent rift system: The example of the Bay of BiscayWestern Pyrenees. Tectonophysics, 489(1-4), 210-226. https://doi.org/10.1016/j.tecto.2010.04.023

Johnson, J. A., \& Hall, C. A. (1989a). Tectono-stratigraphic model for the Massif D'Igountze-Mendibelza, western Pyrenees. Journal of the Geological Society, 146(6), 925. https://doi.org/10.1144/gsjgs.146.6.0925

Johnson, J. A., \& Hall, C. A. (1989b). The structural and sedimentary evolution of the Cretaceous North Pyrenean Basin, southern France. Geological Society of America Bulletin, 101(2), 231-247.

Karner, G. D., \& Driscoll, N. W. (1999). Style, timing and distribution of tectonic deformation across the Exmouth Plateau, northwest Australia, determined from stratal architecture and quantitative basin modelling. Geological Society, London, Special Publications, 164(1), 271-311. https://doi.org/10.1144/GSL.SP.1999.164.01.14

Keen, C. E., Dickie, K., \& Dafoe, L. T. (2018). Structural characteristics of the ocean-continent transition along the rifted continental margin, offshore central Labrador. Marine and Petroleum Geology, 89, 443-463. https://doi.org/10.1016/j.marpetgeo.2017.10.012

Koopmann, H., Brune, S., Franke, D., \& Breuer, S. (2014). Linking rift propagation barriers to excess magmatism at volcanic rifted margins. Geology, 42(12), 1071-1074. https://doi.org/10.1130/G36085.1

Lagabrielle, Y., \& Bodinier, J.-L. (2008). Submarine reworking of exhumed subcontinental mantle rocks: field evidence from the Lherz peridotites, French Pyrenees. Terra Nova, 20(1), 11-21. https://doi.org/10.1111/j.1365-3121.2007.00781.x

Lagabrielle, Y., Labaume, P., \& de Saint Blanquat, M. (2010). Mantle exhumation, crustal denudation, and gravity tectonics during Cretaceous rifting in the Pyrenean realm (SW Europe): Insights from the geological setting of the lherzolite bodies. Tectonics, 29, TC4012. https://doi.org/10.1029/2009TC002588 
Lavier, L. L., \& Manatschal, G. (2006). A mechanism to thin the continental lithosphere at magma-poor margins. Nature, $440,324$.

Leroy, S., Lucazeau, F., d'Acremont, E., Watremez, L., Autin, J., Rouzo, S., et al. (2010). Contrasted styles of rifting in the eastern Gulf of Aden: A combined wide-angle, multichannel seismic, and heat flow survey. Geochemistry, Geophysics, Geosystems, 11, Q07004. https:// doi.org/10.1029/2009GC002963

Lister, G., Etheridge, M., \& Symonds, P. (1986). Detachment faulting and the evolution of passive continental margins. Geology, 14(3), 246-250. https://doi.org/10.1130/0091-7613(1986)14<246:DFATEO >2.0.CO;2

Lucazeau, F., Leroy, S., Bonneville, A., Goutorbe, B., Rolandone, F., d'Acremont, E., et al. (2008). Persistent thermal activity at the Eastern Gulf of Aden after continental break-up. Nature Geoscience, 1(12), 854-858. https://doi.org/10.1038/ngeo359

Masini, E., Manatschal, G., Mohn, G., Ghienne, J.-F., \& Lafont, F. (2011). The tectono-sedimentary evolution of a supra-detachment rift basin at a deep-water magma-poor rifted margin: The example of the Samedan Basin preserved in the Err nappe in SE Switzerland. Basin Research, 23(6), 652-677. https://doi.org/10.1111/j.1365-2117.2011.00509.x

Masini, E., Manatschal, G., Tugend, J., Mohn, G., \& Flament, J.-M. (2014). The tectono-sedimentary evolution of a hyper-extended rift basin: The example of the Arzacq-Mauléon rift system (Western Pyrenees, SW France). International Journal of Earth Sciences, 103(6), 1569-1596. https://doi.org/10.1007/s00531-014-1023-8

McDermott, K., Belligham, P., Pindell, J., Graham, R., \& Horn, B. (2014). Some insights into rifted margin development and the structure of the continent-ocean transition using a global deep seismic reflection database. In Go deep: Back to the source: 4th Atlantic Conjugate Margins Conference Abstracts Volume (pp. 62-65).

McKenzie, D. (1978). Some remarks on the development of sedimentary basins. Earth and Planetary Science Letters, 40(1), 25-32. https:// doi.org/10.1016/0012-821X(78)90071-7

Mohn, G., Karner, G. D., Manatschal, G., \& Johnson, C. A. (2015). Structural and stratigraphic evolution of the Iberia-Newfoundland hyper-extended rifted margin: a quantitative modelling approach. Geological Society, London, Special Publications, 413(1), 53. https://doi. org/10.1144/SP413.9

Montigny, R., Azambre, B., Rossy, M., \& Thuizat, R. (1986). K-Ar study of Cretaceous magmatism and metamorphism in the Pyrenees: Age and length of rotation of the Iberian Peninsula. The Geological Evolution of the Pyrenees, 129(1), 257-273. https://doi.org/10.1016/00401951(86)90255-6

Muñoz, J. A. (1992). Evolution of a continental collision belt: ECORS-Pyrenees crustal balanced cross-section. Thrust Tectonics, 235-246. https://doi.org/10.1007/978-94-011-3066-0_21

Naliboff, J. B., Buiter, S. J. H., Péron-Pinvidic, G., Osmundsen, P. T., \& Tetreault, J. (2017). Complex fault interaction controls continental rifting. Nature Communications, 8(1), 1179. https://doi.org/10.1038/s41467-017-00904-X

Nirrengarten, M., Manatschal, G., Yuan, X. P., Kusznir, N. J., \& Maillot, B. (2016). Application of the critical Coulomb wedge theory to hyper-extended, magma-poor rifted margins. Earth and Planetary Science Letters, 442(Supplement C), 121-132. https://doi.org/10.1016/j. epsl.2016.03.004

Osmundsen, P. T., \& Ebbing, J. (2008). Styles of extension offshore mid-Norway and implications for mechanisms of crustal thinning at passive margins. Tectonics, 27, TC6016. https://doi.org/10.1029/2007TC002242

Pasquale, V., Verdoya, M., \& Chiozzi, P. (2015). Measurements of rock thermal conductivity with a transient divided bar. Geothermics, 53, 183-189. https://doi.org/10.1016/j.geothermics.2014.05.008

Pedreira, D., Pulgar, J. A., Gallart, J., \& Torné, M. (2007). Three-dimensional gravity and magnetic modeling of crustal indentation and wedging in the western Pyrenees-Cantabrian Mountains. Journal of Geophysical Research, 112, B12405. https://doi.org/10.1029/ 2007JB005021

Pérez-Gussinyé, M., \& Reston, T. J. (2001). Rheological evolution during extension at nonvolcanic rifted margins: Onset of serpentinization and development of detachments leading to continental breakup. Journal of Geophysical Research, 106(B3), 3961-3975. https://doi.org/ 10.1029/2000JB900325

Péron-Pinvidic, G., Manatschal, G., Masini, E., Sutra, E., Flament, J. M., Haupert, I., \& Unternehr, P. (2017). Unravelling the along-strike variability of the Angola-Gabon rifted margin: A mapping approach. Geological Society, London, Special Publications, 438(1), 49-76.

Péron-Pinvidic, G., Manatschal, G., \& Osmundsen, P. T. (2013). Structural comparison of archetypal Atlantic rifted margins: A review of observations and concepts. Marine and Petroleum Geology, 43(Supplement C), 21-47. https://doi.org/10.1016/j. marpetgeo.2013.02.002

Person, M., Raffensperger, J. P., Ge, S., \& Garven, G. (1996). Basin-scale hydrogeologic modeling. Reviews of Geophysics, 34(1), 61-87. https://doi.org/10.1029/95RG03286

Pinto, V. H. G., Manatschal, G., Karpoff, A. M., \& Viana, A. (2015). Tracing mantle-reacted fluids in magma-poor rifted margins: The example of Alpine Tethyan rifted margins. Geochemistry, Geophysics, Geosystems, 16, 3271-3308. https://doi.org/10.1002/2015GC005830

Popov, A. A., \& Sobolev, S. V. (2008). SLIM3D: A tool for three-dimensional thermomechanical modeling of lithospheric deformation with elasto-visco-plastic rheology. Recent Advances in Computational Geodynamics: Theory, Numerics and Applications, 171(1), 55-75. https:// doi.org/10.1016/j.pepi.2008.03.007

Puigdefàbregas, C., \& Souquet, P. (1986). Tecto-sedimentary cycles and depositional sequences of the Mesozoic and Tertiary from the Pyrenees. The Geological Evolution of the Pyrenees, 129(1), 173-203. https://doi.org/10.1016/0040-1951(86)90251-9

Ranero, C. R., \& Pérez-Gussinyé, M. (2010). Sequential faulting explains the asymmetry and extension discrepancy of conjugate margins. Nature, 468, 294.

Razin, P. (1989). Evolution tecto-sédimentaire alpine des Pyrénées Basques à l'Ouest de la transformante de Pamplona (province du Labourd).

Reston, T. J., \& McDermott, K. G. (2011). Successive detachment faults and mantle unroofing at magma-poor rifted margins. Geology, 39(11), 1071-1074. https://doi.org/10.1130/G32428.1

Rybacki, E., \& Dresen, G. (2000). Dislocation and diffusion creep of synthetic anorthite aggregates. Journal of Geophysical Research, 105(B11), 26017-26036. https://doi.org/10.1029/2000JB900223

Savva, D., Pubellier, M., Franke, D., Chamot-Rooke, N., Meresse, F., Steuer, S., \& Auxietre, J. L. (2014). Different expressions of rifting on the South China Sea margins. Evolution, structure, and sedimentary record of the South China Sea and adjacent basins, 58(Part B), 579-598 . https://doi.org/10.1016/j.marpetgeo.2014.05.023

Schoeffler, J. (1982). Les transversales basco-landaises. Bulletin Des Centre de Recherches ELF-Aquitaine, 6, 257-263.

Seguret, M. (1972). Étude tectonique des nappes et séries décollées de la partie centrale du versant sud des Pyrénées. Série Géologie structurale, 2, 1-155.

Souche, A., Dabrowski, M., \& Andersen, T. B. (2014). Modeling thermal convection in supradetachment basins: example from western Norway. Geofluids, 14(1), 58-74. https://doi.org/10.1111/gfl.12042 
Souche, A., Schmid, D. W., \& Rüpke, L. (2017). Interrelation between surface and basement heat flow in sedimentary basins. AAPG Bulletin, 101(10), 1697-1713. https://doi.org/10.1306/12051615176

Sutra, E., \& Manatschal, G. (2012). How does the continental crust thin in a hyperextended rifted margin? Insights from the Iberia margin Geology, 40(2), 139-142. https://doi.org/10.1130/G32786.1

Sutra, E., Manatschal, G., Mohn, G., \& Unternehr, P. (2013). Quantification and restoration of extensional deformation along the Western Iberia and Newfoundland rifted margins. Geochemistry, Geophysics, Geosystems, 14, 2575-2597. https://doi.org/10.1002/ggge.20135

Svartman Dias, A. E., Lavier, L. L., \& Hayman, N. W. (2015). Conjugate rifted margins width and asymmetry: The interplay between lithospheric strength and thermomechanical processes. Journal of Geophysical Research: Solid Earth, 120, 8672-8700. https://doi.org/ $10.1002 / 2015 J B 012074$

Taylor, G. H., Teichmüller, M., Davis, A., Diessel, C., Littke, R., \& Robert, P. (1998). Organic petrology.

Teixell, A. (1990). Alpine thrusts at the western termination of the Pyrenean axial zone. Bulletin de La Societe Geologique de France, VI(2), 241. https://doi.org/10.2113/gssgfbull.VI.2.241

Teixell, A. (1998). Crustal structure and orogenic material budget in the west central Pyrenees. Tectonics, 17(3), 395-406. https://doi.org/ $10.1029 / 98 \mathrm{TC} 00561$

Tesauro, M., Kaban, M. K., \& Cloetingh, S. A. P. L. (2009). A new thermal and rheological model of the European lithosphere. Tectonophysics, 476(3), 478-495. https://doi.org/10.1016/j.tecto.2009.07.022

Tetreault, J. L., \& Buiter, S. J. H. (2017). The influence of extension rate and crustal rheology on the evolution of passive margins from rifting to break-up. Tectonophysics.. https://doi.org/10.1016/j.tecto.2017.08.029

Theissen, S., \& Rüpke, L. H. (2009). Feedbacks of sedimentation on crustal heat flow: New insights from the Vøring Basin, Norwegian Sea. Basin Research, 22. https://doi.org/10.1111/j.1365-2117.2009.00437.x

Thiébaut, J., Debeaux, M., Durand-Wackenheim, C., Souquet, P., Gourinard, Y., Bandet, Y., \& Fondecave-Wallez, M.-J. (1988). Métamorphisme et halocinèse crétacés dans les évaporites de Betchat le long du chevauchement frontal Nord-Pyrénéen (Haute-Garonne et Ariège, France). Comptes Rendus de l'Académie Des Sciences. Série 2, Mécanique, Physique, Chimie, Sciences de l'univers. Sciences de La Terre, 307(13), 1535-1540.

Torne, M., Fernàndez, M., Vergés, J., Ayala, C., Salas, M. C., Jimenez-Munt, I., et al. (2015). Crust and mantle lithospheric structure of the Iberian Peninsula deduced from potential field modeling and thermal analysis. Tectonophysics, 663, 419-433. https://doi.org/10.1016/j. tecto.2015.06.003

Tugend, J., Manatschal, G., \& Kusznir, N. J. (2015). Spatial and temporal evolution of hyperextended rift systems: Implication for the nature, kinematics, and timing of the Iberian-European plate boundary. Geology, 43(1), 15-18. https://doi.org/10.1130/G36072.1

Tugend, J., Manatschal, G., Kusznir, N. J., \& Masini, E. (2015). Characterizing and identifying structural domains at rifted continental margins: application to the Bay of Biscay margins and its Western Pyrenean fossil remnants. Geological Society, London, Special Publications, 413(1), 171. https://doi.org/10.1144/SP413.3

Tugend, J., Manatschal, G., Kusznir, N. J., Masini, E., Mohn, G., \& Thinon, I. (2014). Formation and deformation of hyperextended rift systems: Insights from rift domain mapping in the Bay of Biscay-Pyrenees. Tectonics, 33, 1239-1276. https://doi.org/10.1002/ 2014TC003529

Ungerer, P., Burrus, J., Doligez, B., Chenet, P. Y., \& Bessis, F. (1990). Basin evaluation by integrated two-dimensional modeling of heat transfer, fluid flow, hydrocarbon generation, and migration. AAPG Bulletin (American Association of Petroleum Geologists); (USA) Retrieved from http://www.osti.gov/scitech/servlets/purl/6990099

Vacherat, A., Mouthereau, F., Pik, R., Bernet, M., Gautheron, C., Masini, E., et al. (2014). Thermal imprint of rift-related processes in orogens as recorded in the Pyrenees. Earth and Planetary Science Letters, 408(Supplement C), 296-306. https://doi.org/10.1016/j. epsl.2014.10.014

Velasque, P. C., Ducasse, L., Muller, J., \& Scholten, R. (1989). The influence of inherited extensional structures on the tectonic evolution of an intracratonic chain: The example of the Western Pyrenees. Tectonophysics, 162(3-4), 243-264. https://doi.org/10.1016/0040-1951(89) 90247-3

Vilà, M., Fernández, M., \& Jiménez-Munt, I. (2010). Radiogenic heat production variability of some common lithological groups and its significance to lithospheric thermal modeling. Tectonophysics, 490(3-4), 152-164. https://doi.org/10.1016/j.tecto.2010.05.003

Wang, Y., Chevrot, S., Monteiller, V., Komatitsch, D., Mouthereau, F., Manatschal, G., et al. (2016). The deep roots of the western Pyrenees revealed by full waveform inversion of teleseismic P waves. Geology, 44(6), 475-478. https://doi.org/10.1130/G37812.1

Yamato, P., Burov, E., Agard, P., Le Pourhiet, L., \& Jolivet, L. (2008). HP-UHP exhumation during slow continental subduction: Selfconsistent thermodynamically and thermomechanically coupled model with application to the Western Alps. Earth and Planetary Science Letters, 271, 63-74. https://doi.org/10.1016/j.epsl.2008.03.049 